\title{
Cyclic Oligophosphonic Anhydrides Stable in Aqueous Media
}

\author{
Ivan S. Alferiev* and Sergey Yu. Bobkov \\ Institute of Chemical Kinetics and Combustion, Novosibirsk 630090, Russia
}

Z. Naturforsch. 47 b, 1213-1224 (1992); received March 26, 1992

Amides, Phosphonylation, 1-Alkylaminoalkane-1,1,3,3-tetrayl-tetrakis-phosphonic Anhydrides, Cyclic Dimeric Anhydrides, 1-Aminoalkylidene-1,1-bis-phosphonic Acids

Depending on reaction conditions, the phosphonylation of $\mathrm{N}$-alkylacetamides with $\mathrm{H}_{3} \mathrm{PO}_{3}-\mathrm{PCl}_{3}$ in $\mathrm{B} \cdot \mathrm{HCl}$ media $\left(\mathrm{B}=\mathrm{Py}, \mathrm{Bu}_{3} \mathrm{~N}\right)$ gives either 1-alkylaminoethylidene-1,1-bisphosphonic acids $(\mathbf{1} \mathbf{a}-\mathbf{e})$ or previously unknown 1 -alkylaminobutane-1,1,3,3-tetrayl-tetrakisphosphonic dianhydrides $(\mathbf{2} \mathbf{a}-\mathbf{e})$. The latter convert into monocyclic forms $(\mathbf{3} \mathbf{a}-\mathbf{e})$ under mild acidic hydrolysis. Acyclic forms $(4 \mathbf{a}-\mathbf{e})$ cannot be isolated. In the presence of higher N,N-dialkylamides the phosphonylation of acetamides affords the higher dianhydrides $(\mathbf{2} \mathbf{f}-\mathbf{h})$. Strong acidic hydrolysis of $\mathbf{2}$ or $\mathbf{3}$ yields 3,3-diphosphonocarboxylic acids $(\mathbf{5} \mathbf{a}-\mathbf{c})$. Reacting with $\mathrm{H}_{3} \mathrm{PO}_{3}-\mathrm{PHal}_{3}$ in $\mathrm{B} \cdot \mathrm{HHal}(\mathrm{Hal}=\mathrm{Cl}, \mathrm{Br})$, the amides $\mathrm{R}^{1} \mathrm{CONHR}{ }^{2}\left(\mathrm{R}^{1} \neq \mathrm{H}, \mathrm{Me} ; \mathrm{R}^{2}=\right.$ Alk, H) give both N-alkyl- (or N-unsubstituted) 1-aminoalkylidene-1,1-bis-phosphonic acids $(6 \mathbf{a}-\mathbf{j})$ and their cyclic dimeric anhydrides $(7 \mathbf{a}-\mathbf{g}, \mathbf{i}, \mathbf{j})$.

Oligophosphonates have many applications owing to their chelating ability [1]. The phosphonylation of carboxylic acids [2, 3] or their nitrogen-containing derivatives (amides, nitriles) [4, 3] with $\mathrm{H}_{3} \mathrm{PO}_{3}-\mathrm{PHal}_{3}$ systems is the most applicable method for the synthesis of two important classes of oligophosphonates, namely 1-hydroxy- and 1-aminoalkylidene-1,1-bis-phosphonic acids. The main feature of these related reactions is the necessity for dehydrating conditions (the reaction mixtures should be capable of binding $\geqslant 1 \mathrm{~mol}$ of water per $1 \mathrm{~mol}$ of trivalent phosphorus entered into the reaction, otherwise, the yields of the bis-phosphonic acids decrease dramatically, $c f$. [5]). As a result, polycondensation of the reaction products occurs, leading to thickening and even to solidification of the reaction mixtures. Inefficient mixing of reactants does not allow high yields of the phosphonylation products to be obtained. Dilution of the reaction mixtures with an excess (from 2- to 3 -fold over the stoichiometric ratio) of acyl-containing component is only successful in the phosphonylation of some lower carboxylic acids, but fails in the case of amides.

Previously [6], we proposed the use of amine hydrohalides (salts of tri- and dialkylamines, pyridine, etc.) as diluents of reaction mixtures in the phosphonylation of carboxylic acids and formam-

\footnotetext{
* Reprint requests to Dr. I. S. Alferiev.

Verlag der Zeitschrift für Naturforschung, D-W-7400 Tübingen

0932-0776/92/0900-1213/\$ 01.00/0
}

ides. The use of amine hydrohalides (from 30 to $300 \%$ by weight relative to the acyl-containing component) was shown to prevent the solidification of the reaction mixtures and to increase the yields of the desired bis-phosphonic acids. No unusual products were observed. In contrast, the application of this method to amides other than formamides gave a series of unexpected products.

\section{Results}

The reaction with amides was carried out at 80- $100{ }^{\circ} \mathrm{C}$ using molar ratios

$\left(\mathrm{H}_{3} \mathrm{PO}_{3}+\mathrm{PHal}_{3}\right)$ : amide $\geqslant 2.5: 1$ (to ensure sufficient excess of trivalent $\mathrm{P}$ ) and $\mathrm{PHal}_{3}: \mathrm{H}_{3} \mathrm{PO}_{3}$ close to $0.85: 1$ (to create the necessary dehydrating ability of reaction mixtures). As a rule, $\mathrm{PCl}_{3}$ was used (and amine hydrochlorides, respectively), but in some special cases it was replaced by $\mathrm{PBr}_{3}$ (and amine hydrobromides). Mostly, the reaction mixtures with $\mathrm{PBr}_{3}$ showed much weaker activity in the phosphonylation than did those with $\mathrm{PCl}_{3}$, except of the cases which required higher acidity. Hydrohalides of pyridine or tributylamine (from 150 to $500 \mathrm{~g}$ per $1 \mathrm{~mol}$ of amide) were preferably used, chlorobenzene or $o$-dichlorobenzene being introduced as additional diluents to further reduce the viscosity of the reaction mixtures. When the reaction was complete, the mixtures were hydrolyzed with an excess of water to destroy the unstable polycondensated products and were analyzed using ${ }^{31} \mathrm{P}$ NMR. Yields of the phosphonylation products were calculated for the amides based on the data of NMR spectroscopic analysis. 
The phosphonylation of N-monoalkylacetamides with $\mathrm{H}_{3} \mathrm{PO}_{3}-\mathrm{PCl}_{3}$ under relatively mild conditions (at $80-85^{\circ} \mathrm{C}$ ) gives after hydrolysis the expected 1-alkylaminoethylidene-1,1-bis-phosphonic acids $(\mathbf{1 a}-\mathbf{e})$ in high yields. However, an insignificant raise of temperature (by $\mathrm{ca} .10^{\circ} \mathrm{C}$ ) leads to dimerization of $1 \mathbf{a}-\mathbf{e}$ followed by loss of one alkylamino group and the formation of bicyclic 1-alkylaminobutane-1,1,3,3-tetrayl-tetrakis-phosphonic 1,3,1,3-dianhydrides $(\mathbf{2} \mathbf{a}-\mathbf{e})$. Under controlled acidic hydrolysis, the latter are converted into the monocyclic forms $(\mathbf{3 a}-\mathbf{e})$. Both $\mathbf{2}$ and $\mathbf{3}$ are stable in neutral or slightly alkaline aqueous solutions and may be isolated either as free acids or as salts.

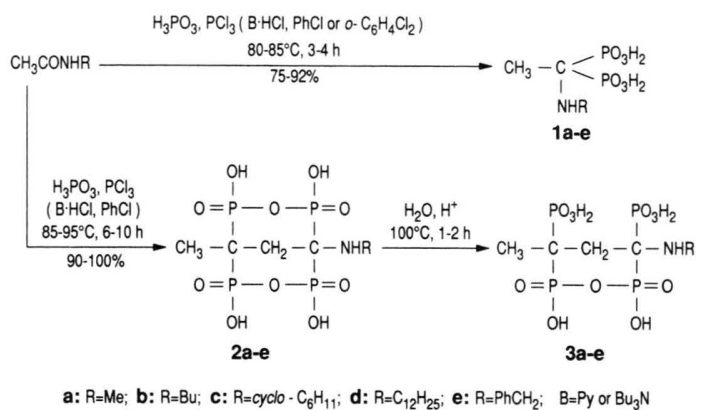

It should be stressed that not free acids $\mathbf{1}$, but their oligomeric anhydrides (existing under dehydrating reaction conditions) are the precursors of $\mathbf{2}$ in this dimerizing phosphonylation of acetamides. Non-anhydride forms of $\mathbf{1}$ are rather stable compounds and do not change even at much higher temperatures. The tendency to the dimerizing phosphonylation grows with increasing steric hindrance created by the N-substituent R. Under the same conditions $\left(83-85^{\circ} \mathrm{C}, 4 \mathrm{~h}\right), \mathrm{N}$-methyland N-butylacetamides form only $\mathbf{1 a}$ and $\mathbf{1 b}$, respectively, $\mathrm{N}$-dodecylacetamide gives nearly equal amounts of $\mathbf{1 d}$ and $\mathbf{2 d}$, whereas N-cyclohexylacetamide yields almost only $\mathbf{2 c}$. An additional excess of trivalent $\mathrm{P}$ is necessary to avoid the formation of $\mathbf{2}$ in two last cases.

In order to account for this unexpected reaction route, we propose that imine $\mathrm{CH}_{3} \mathrm{C}\left(\mathrm{POX}_{2}\right)=\mathrm{NR}$ $\left(\mathrm{POX}_{2}\right.$ means anhydridized $\left.\mathrm{PO}_{3} \mathrm{H}_{2}\right)$ is the major intermediate. This imine may form due to both the phosphonylation of acetamide and the reverse dephosphonylation of $\mathbf{1}$. Tautomerization gives the $\mathrm{C}$-nucleophilic enamine $\mathrm{CH}_{2}=\mathrm{C}\left(\mathrm{POX}_{2}\right)-\mathrm{NHR}$ whereas protonation affords the C-electrophile. Their interaction leads to the formation of a new $\mathrm{C}-\mathrm{C}$ bond and ultimately yields $\mathbf{2}$. This supposition is consistent with the above-mentioned influence of the $\mathrm{N}$-substituent on the reaction pathway. Bulky groups R shift the equilibrium of the phosphonylation towards the imine and, hence, increase the rate of dimerization. As one would expect, no $\mathrm{C}-\mathrm{C}$ bond formation was found to accompany the phosphonylation of $\mathrm{N}$-unsubstituted acetamide.

The rôle of amine hydrochloride appears to be to lower the acidity of the reaction medium, thus favouring the formation of the enamine. The unusual sensitivity of the reaction to the raise of temperature may be explained by the same reason. Heating the reaction mixtures (even by $10{ }^{\circ} \mathrm{C}$ ) significantly decreases the concentration of dissolved $\mathrm{HCl}$, thus lowering the acidity and activating the conversion of $\mathbf{1}$ into $\mathbf{2}$. High molar concentrations of amine hydrochlorides appreciably accelerate the dimerizing phosphonylation and increase the yields of 2. Pyridine hydrochloride seems to be the best medium for this reaction because of its low molecular mass and high liquidizing ability. The replacement of $\mathrm{PCl}_{3}$ by $\mathrm{PBr}_{3}$ increases the acidity and prevents the dimerization of $\mathbf{1}$.

When $\mathrm{N}$-alkylacetamides are introduced into the reaction in the presence of higher N,N-dialkylamides (which cannot yield any stable phosphonylation products without $\mathrm{C}-\mathrm{N}$ bond rupture), the latter provide the major part of $\mathrm{C}$-electrophilic species. Therefore, the higher cyclic anhydrides $(\mathbf{2} \mathbf{f}-\mathbf{h})$ become the main products.

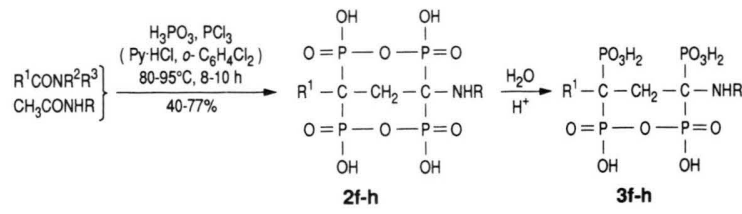

f: $R^{1}=C_{7} H_{15}, R=B u ; g: R^{1}=C_{11} H_{23}, R=B u ; h: R^{1}=C_{7} H_{15}, R=P h C H_{2} ; R^{2}=R^{3}=M e$ or $R^{2} \cdot R^{3}=\left(C_{2}\right)_{4},\left(C_{2}\right)_{5}$

It is clear that the lower homologues $\mathbf{2 b}$ or $\mathbf{2 e}$ must form simultaneously. In spite of the structural similarity, $\mathbf{2} \mathbf{f}-\mathbf{h}$ and $\mathbf{2} \mathbf{b}$, e may be distinguished using ${ }^{31} \mathrm{P}$ NMR. Thus, the yields of both the higher and the lower homologues may be determined. It is found that the maximum yields of $\mathbf{2} \mathbf{f}-\mathbf{h}$ and, respectively, the minimum yields of $\mathbf{2} \mathbf{b}, \mathbf{e}$ can be at- 
tained using two-stage heating. At the first stage the mixtures should be kept at lower temperatures, which exclude formation of $\mathbf{2}$. The temperature ought to be raised only after complete conversion of the $\mathrm{N}$-alkylacetamide into the corresponding $\mathbf{1}$. The $\mathbf{2 f : 2 b}$ ratio in the reaction of N-butylacetamide with equimolar amounts of various $\mathrm{N}, \mathrm{N}$-dialkylcaprylamides is found to depend also on the radicals $\mathrm{R}^{2}$ and $\mathrm{R}^{3}$. Under the best found reaction conditions, the molar ratio $\mathbf{2} \mathbf{f}: \mathbf{2} \mathbf{b}$ is $14: 1$ for $\mathrm{R}^{2}-\mathrm{R}^{3}=\left(\mathrm{CH}_{2}\right)_{4}, 3: 1$ for $\mathrm{R}^{2}=\mathrm{R}^{3}=\mathrm{Me}$ and $1: 1$ for $\mathrm{R}^{2}-\mathrm{R}^{3}=\left(\mathrm{CH}_{2}\right)_{5}$. Both phenomena are in agreement with our suggestions concerning the reaction mechanism. Complete conversion of $\mathrm{N}$-alkylacetamide into 1 decreases the concentration of the imine to the equilibrious one, thus retarding the formation of $\mathbf{2} \mathbf{b}$, $\mathbf{e}$ to a greater extent than that of $\mathbf{2} \mathbf{f}-\mathbf{h}$. Sterically unhindered N-acyl- pyrrolidine affords the most reactive C-electrophilic species.

Similarly to the lower homologues $2 \mathbf{a}-\mathbf{e}$, the anhydrides $\mathbf{2} \mathbf{f}-\mathbf{h}$ undergo hydrolysis to the monocyclic forms ( $\mathbf{3} \mathbf{f}-\mathbf{h})$, but significantly (by $c a$. an order of magnitude) slower. This is apparently due to relative stabilization of the bicyclic form when both the radicals $\mathrm{R}$ and $\mathrm{R}^{1}$ are rather bulky. When only the N-substituent is bulky (e.g. for $\mathbf{2 d}$ ), the hydrolysis is not retarded appreciably.

The ${ }^{31} \mathrm{P}\left\{{ }^{1} \mathrm{H}\right\}$ decoupled NMR spectra of $\mathbf{2}$ (Table I) show a picture typical of $\mathrm{AA}^{\prime} \mathrm{BB}^{\prime}$ systems, which may be approximately described as two dd, with several small peaks being neglected. The spectra of $\mathbf{3}$ (Table II) exhibit four sorts of ${ }^{31} \mathrm{P}$ and three marked coupling constants. Assignment of ${ }^{31} \mathrm{P}$ signals in both cases is based on proton couplings. The ${ }^{31} \mathrm{P}$ signals coupled with the greater

\begin{tabular}{|c|c|c|c|c|c|c|}
\hline Compound & $\mathrm{R}$ & $\mathrm{R}^{1}$ & $\begin{array}{l}\delta[\mathrm{ppm} \\
\mathrm{P}^{\mathrm{l}}\end{array}$ & $\mathrm{P}^{2}$ & $\begin{array}{l}J[\mathrm{~Hz}] \\
\mathrm{AB}\end{array}$ & $\mathrm{AB}^{\prime}$ \\
\hline $\begin{array}{l}2 \mathbf{a}^{\mathrm{a}} \\
2 \mathbf{b}^{\mathrm{a}} \\
2 \mathbf{c} \\
2 \mathbf{d} \\
2 \mathrm{e}^{\mathrm{a}} \\
\mathbf{2 f} \\
2 \mathbf{g} \\
2 \mathbf{h}^{\mathrm{a}}\end{array}$ & $\begin{array}{l}\mathrm{Me} \\
\mathrm{Bu} \\
-\mathrm{C}_{6} \mathrm{H}_{11} \\
\mathrm{C}_{12} \mathrm{H}_{25} \\
\mathrm{PhCH}_{2} \\
\mathrm{Bu} \\
\mathrm{Bu} \\
\mathrm{PhCH}\end{array}$ & $\begin{array}{l}\mathrm{Me} \\
\mathrm{Me} \\
\mathrm{Me} \\
\mathrm{Me} \\
\mathrm{Me} \\
\mathrm{C}_{7} \mathrm{H}_{15} \\
\mathrm{C}_{11} \mathrm{H}_{23} \\
\mathrm{C}_{7} \mathrm{H}_{15} \\
\quad \mathrm{HO} \\
\quad \mathrm{R}^{1} \\
\mathrm{HO}\end{array}$ & $\begin{array}{l}+15.1 \\
+14.8 \\
+14.8 \\
+14.7 \\
+14.7 \\
+13.5 \\
+13.3 \\
+13.5 \\
1-0- \\
-\mathrm{CH}_{2}- \\
1-\mathrm{O}-\end{array}$ & $\begin{array}{l}+10.3 \\
+10.3 \\
+10.4 \\
+10.3 \\
+10.0 \\
+9.7 \\
+9.8 \\
+9.4 \\
\text { OH } \\
\text { HHR }\end{array}$ & $\begin{array}{l}21 \\
21 \\
21 \\
21 \\
22 \\
23 \\
23 \\
23\end{array}$ & $\begin{array}{l}8 \\
8 \\
8 \\
8 \\
7 \\
8 \\
8 \\
8\end{array}$ \\
\hline
\end{tabular}

Table I. ${ }^{31} \mathrm{P}$ NMR data for $\mathbf{2} \mathbf{a}-\mathbf{h}$ (AA'BB' systems with ${ }^{1} \mathrm{H}$ decoupled).

${ }^{a}$ Compound was not isolated; ${ }^{\mathrm{b}}$ chemical shifts depend on $\mathrm{Et}_{2} \mathrm{NH}$ quantity, variations up to $0.5 \mathrm{ppm}$ are possible.

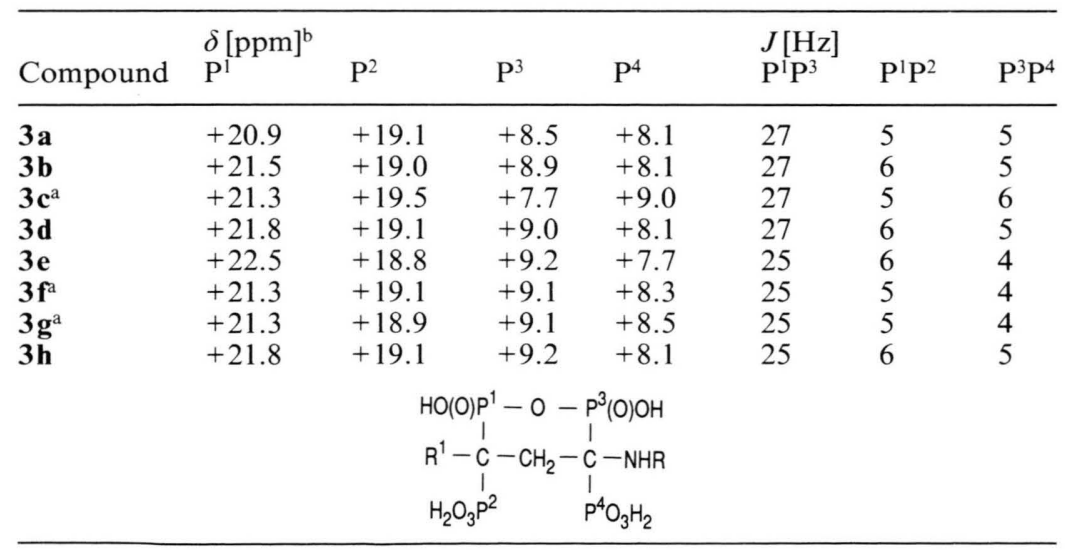

Table II. ${ }^{31} \mathrm{P}$ NMR data for $\mathbf{3 a} \mathbf{a}$.

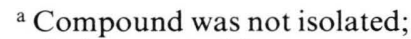
${ }^{\mathrm{b}}$ variations up to $0.7 \mathrm{ppm}$. 
number of protons are assigned to the atoms in 3-position relative to the amino group. Only one of the two possible diastereomers is detected in the spectra of both pure 3 and their reaction mixtures.

The phosphonylation of $\mathrm{N}$-dodecylacetoacetamide with $\mathrm{H}_{3} \mathrm{PO}_{3}-\mathrm{PCl}_{3}$ has been found to give $\mathbf{2 ~ d}$ in a high yield. This eliminates all doubts concerning the structure of anhydrides 2 and 3. However, it is hardly probable for $\mathrm{N}$-alkylacetoacetamides to be precursors of $\mathbf{2}$ in the dimerizing phosphonylation. N-Alkylacetamides fail to dimerize when being heated with $\mathrm{H}_{3} \mathrm{PO}_{4}-\mathrm{POCl}_{3}$ under conditions similar to those of their reaction with $\mathrm{H}_{3} \mathrm{PO}_{3}-\mathrm{PCl}_{3}$. Evidently, the phosphonylation of acetamides really precedes the formation of a new $\mathrm{C}-\mathrm{C}$ bond.

In acidic media the anhydrides $\mathbf{3 a - e}$ undergo reversible ring-opening, giving non-anhydride forms $(4 \mathbf{a}-\mathbf{e})$. Rough estimations show that the equilibrium ratios of $4: 3$ hardly exceed $1 / 4$. An excess of $\mathrm{KOH}$ gives rise to practically a full conversion of $\mathbf{3 a}$ into $\mathbf{4 a}$, but at lower $\mathrm{pH}$ reverse cyclization occurs. Evidently, none of $\mathbf{4}$ can be isolated. ${ }^{31} \mathrm{P}$ NMR data for $\mathbf{4 a - e}$ (Table III) have been ob-

Table III. ${ }^{31}$ P NMR data for $\mathbf{4 a - e . ~}$



tained from the spectra of their mixtures with corresponding 3. Higher anhydrides $\mathbf{3 f}-\mathbf{h}$ produce negligible amounts of acyclic forms.

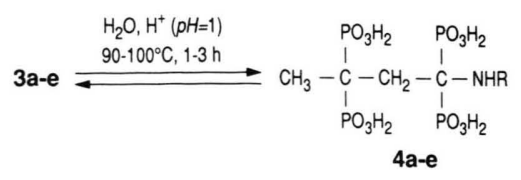

Hydrolysis of $\mathbf{2}$ or $\mathbf{3}$ with refluxing azeotropic $\mathrm{HCl}$ or $\mathrm{HBr}$ leads to the elimination of alkylamine and two $\mathrm{H}_{3} \mathrm{PO}_{3}$ molecules, which yields 3,3-diphosphonocarboxylic acids $(\mathbf{5} \mathbf{a}-\mathbf{c})$.

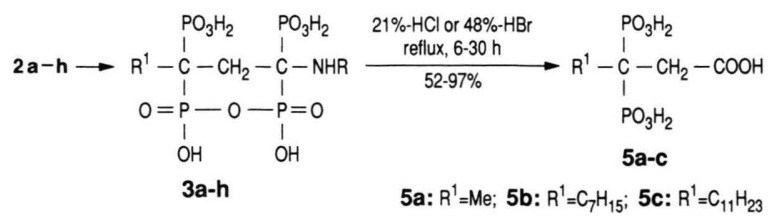

Formation of $\mathbf{5}$ is accompanied by a side reaction, giving $\mathrm{H}_{3} \mathrm{PO}_{4}$ and unidentified reduction products (probably 1-alkylaminoalkane-1,3,3-triyltris-phosphonic acids). The latter are resistant to hydrolysis and complicate the subsequent isolation of 5. The more bulky $\mathrm{R}$ and the less bulky $\mathrm{R}^{1}$, the higher the yields of $\mathbf{5}$ (Table IV) and the faster the hydrolysis. The lowest yield of $\mathbf{5} \mathbf{b}$ in destruction of $\mathbf{3 h}$ is most likely due to rapid debenzylation of the latter under the reaction conditions. Solely $\mathbf{5 a}$ is isolated, the formation of $\mathbf{5} \mathbf{b}, \mathbf{c}$ is detected only by NMR.

So far, all attempts to introduce $\mathrm{N}$-monoalkylamides of other aliphatic carboxylic acids into reactions similar to the dimerizing phosphonylation of acetamides have failed. Reactions of

Table IV. Strong acidic hydrolysis of $\mathbf{2}$ and $\mathbf{3}$ to $\mathbf{5} \mathbf{a}-\mathbf{c}$.

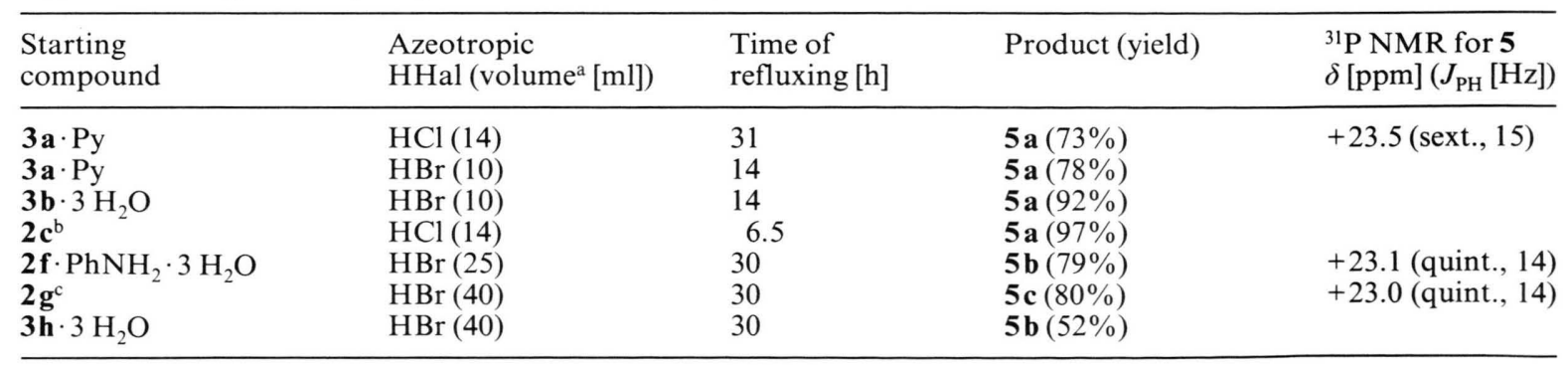

${ }^{\mathrm{a}}$ Per $1 \mathrm{~g}$ of starting compound; ${ }^{\mathrm{b}}$ solvate with $i$ - $\mathrm{PrOH}(\mathrm{M}=536.0) ;{ }^{\mathrm{c}}$ non-stoichiometric $\mathrm{PhNH}_{2}$ salt $(\mathrm{M}=780)$. 
these, and also of the aromatic N-monoalkylamides with $\mathrm{H}_{3} \mathrm{PO}_{3}-\mathrm{PCl}_{3}$, afford oligomeric anhydrides of ordinary 1-alkylaminoalkylidene-1,1-bisphosphonic acids. However, in most cases hydrolysis of the reaction mixtures gives only low yields of monomers $(6 \mathbf{a}-\mathbf{h})$, the major products being previously unknown cyclic dimers $(\mathbf{7} \mathbf{a}-\mathbf{g})$ stable to hydrolysis. None of other phosphonylation products are formed under mild reaction conditions. The yields of 7 (Table $\mathrm{V}$ ) depend on both $\mathrm{R}^{1}$ and $\mathrm{R}^{2}$. Despite the limited number of tested amides, some regularities may be marked. Small $\mathrm{R}^{2}$ and relatively large $R^{1}$ favour the formation of 7 . When the length of $\mathrm{R}^{2}$ is more than a certain critical value, no 7 forms. E.g., N-hexylvaleramide yields mainly dimer $\mathbf{7 g}$, whereas $\mathrm{N}$-octylvaleramide gives only monomeric $\mathbf{6 h}$. The critical length of $\mathrm{R}^{2}$ should, clearly, depend on $\mathrm{R}^{1}$. Since such dimeric anhydrides have never been observed in the mentioned reaction mixtures of acetamides, for $\mathrm{R}^{1}=\mathrm{Me}$ the length of any substituent $\mathrm{R}^{2}$ already exceeds the critical value.

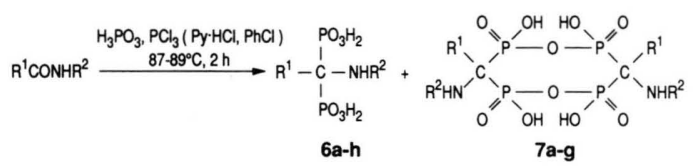

a: $R^{1}=E t, R^{2}=M e ; ~ b: ~ R^{1}=B u, R^{2}=M e ; c: R^{1}=C_{7} H_{15}, R^{2}=M e ; d: R^{1}=C_{11} H_{23}, R^{2}=M e ;$ e: $R^{1}=p-M e-C_{6} H_{4}, R^{2}=M e ; f: R^{1}=B u, R^{2}=B u ; g: R^{1}=B u, R^{2}=C_{6} H_{13} ; \mathbf{h}: R^{1}=B u, R^{2}=C_{8} H_{17}$

Under dehydrating reaction conditions, N-unsubstituted amides transform into nitriles. With the exception of lower homologues, the latter are hardly capable of phosphonylation with $\mathrm{H}_{3} \mathrm{PO}_{3}-\mathrm{PCl}_{3}$ due to low acidity of the reaction medium. The use of the $\mathrm{H}_{3} \mathrm{PO}_{3}-\mathrm{PBr}_{3}$ system succeeds in phosphonylation of higher unsubstituted amides or nitriles and gives dimers $(\mathbf{7} \mathbf{i}, \mathbf{j})$ in high yields. The reaction time should be long enough, otherwise the known monomeric acids $(\mathbf{6} \mathbf{i}, \mathbf{j})$ become the major products. Propionamide and propionitrile form none of the expected lower dimeric anhydrides, the known 1-aminopropylidene-1,1-bis-phosphonic acid being the only detectable product. As regards the phosphonylation of $\mathrm{N}$-alkylacetamides, the system $\mathrm{H}_{3} \mathrm{PO}_{3}-\mathrm{PBr}_{3}$ shows much weaker reactivity as compared to $\mathrm{H}_{3} \mathrm{PO}_{3}-\mathrm{PCl}_{3}$, giving lower yields of dimers $7 \mathbf{a}-\mathbf{g}$.



The formation of dimers 7 in the previously rather well studied reaction [7] requires some explanations. We suppose that two sorts of 1-aminoor 1-N-alkylaminoalkylidene-1,1-bis-phosphonic anhydrides may exist under dehydrating conditions of the phosphonylation. In aqueous medium one of them undergoes rapid hydrolysis to monomeric 6, whereas another (namely 7) remains unchanged. The ratio between these two sorts of anhydrides seems to be under thermodynamic con-

Table V. Phosphonylation of the $\mathrm{N}$-alkylamides $\mathrm{R}^{1} \mathrm{CONHR}{ }^{2}$ with $\mathrm{H}_{3} \mathrm{PO}_{3}-\mathrm{PCl}_{3}$ and ${ }^{31} \mathrm{P}$ NMR data for the reaction products.

\begin{tabular}{|c|c|c|c|c|c|}
\hline $\begin{array}{l}\text { Starting amide } \\
\mathrm{R}^{1}\end{array}$ & $\mathrm{R}^{2}$ & $\begin{array}{l}\text { Products }\left(\text { yields }{ }^{\mathrm{a}}\right) \\
\text { monomer }\end{array}$ & dimer & $\begin{array}{l}{ }^{31} \mathrm{P} \text { NMR data } \\
\delta \text { [ppm] (multipl. }{ }^{\mathrm{b}}, J_{\mathrm{PH}} \\
\text { for monomer }\end{array}$ & $\begin{array}{l}[\mathrm{Hz}]) \\
\text { for dimer }\end{array}$ \\
\hline Et & $\mathrm{Me}$ & $6 \mathbf{a}(10 \%)$ & $7 \mathbf{a}(85 \%)^{\mathrm{d}}$ & $+12.0(\mathrm{t}, 13)$ & $+6.3(\mathrm{~m})$ \\
\hline $\mathrm{Bu}$ & $\mathrm{Me}$ & $6 \mathbf{b}(8 \%)$ & $7 \mathbf{b}(88 \%)^{e}$ & $+11.8(\mathrm{t}, 11)$ & $+6.7(\mathrm{~m})$ \\
\hline $\mathrm{C}_{7} \mathrm{H}_{15}$ & $\mathrm{Me}$ & $6 c(9 \%)$ & $7 \mathbf{c}(89 \%)$ & $+12.2(\mathrm{t}, 11)$ & $+7.0(\mathrm{~m})$ \\
\hline $\mathrm{C}_{11} \mathrm{H}_{23}$ & $\mathrm{Me}$ & $6 d(7 \%)^{f}$ & $7 d(91 \%)^{f}$ & $+12.4(\mathrm{t}, 11)$ & $+7.2(\mathrm{~m})$ \\
\hline$p-\mathrm{Me}^{23}-\mathrm{C}_{6} \mathrm{H}_{4}$ & $\mathrm{Me}$ & $6 \mathrm{e}(5 \%)$ & 7 e $(82 \%)$ & $+13.4(\mathrm{~s})$ & $+7.0(\mathrm{~s})$ \\
\hline $\mathrm{Bu}$ & $\mathrm{Bu}$ & $6 f(11 \%)$ & $7 \mathbf{f}(85 \%)$ & $+11.6(\mathrm{t}, 12)$ & $+6.4(\mathrm{~m})$ \\
\hline $\mathrm{Bu}$ & $\mathrm{C}_{6} \mathrm{H}_{13}$ & $6 \mathrm{~g}(25 \%)$ & $7 \mathrm{~g}(70 \%)$ & $+12.2(\mathrm{t}, 12)$ & $+6.9(\mathrm{~m})$ \\
\hline $\mathrm{Bu}$ & $\mathrm{C}_{8} \mathrm{H}_{17}$ & $6 \mathrm{~h}(94 \%)$ & - & $+12.5(\mathrm{t}, 12)$ & - \\
\hline
\end{tabular}

\footnotetext{
${ }^{a}$ Based on ${ }^{31} \mathrm{P}$ NMR analysis; ${ }^{\mathrm{b}}$ with ${ }^{1} \mathrm{H}$ decoupled all signals are singlets; ${ }^{\mathrm{c}}$ only $\mathbf{6 h}$ was isolated; ${ }^{\mathrm{d}}$ additionally, the probable minor isomer $(3 \%)$ is observed at $4.4 \mathrm{ppm} ;{ }^{\mathrm{e}}$ probable minor isomer $(<2 \%)$ at 4.5 ppm; ${ }^{\mathrm{f}}$ only precipitate was analyzed.
} 
trol. Probably, high concentrations of amine hydrohalides increase the stability of 7. Low viscosity of the reaction media accelerates the rearrangement of the labile sort into the stable one.

The water solubility of free acids 7 and their salts is significantly lower than that of corresponding 6. The ${ }^{31} \mathrm{P}$ NMR spectra of 7 indicate the equivalency of all $\mathrm{P}$ atoms, the ${ }^{31} \mathrm{P}$ signals (at $6-7 \mathrm{ppm}$ for $\mathbf{7} \mathbf{a}-\mathbf{g}$ and $11-12$ ppm for $\mathbf{7} \mathbf{i}, \mathbf{j}$ ) being shifted by $c a .5$ ppm upfield relative to those of 6 with the same substituents. Mainly one of the two possible diastereomers of $\mathbf{7}$ is realized. Probably, the minor diastereomers exist in the reaction mixtures of $\mathbf{7 a - c}$ (additional ${ }^{31} \mathrm{P}$ signals at $4-5 \mathrm{ppm}$ ), but in negligible amounts.

The anhydrides 7 remain unchanged for at least $5 \mathrm{~h}$ at $100{ }^{\circ} \mathrm{C}$ in aqueous solutions as the free acid forms and also as salts, even in the presence of $1 \mathrm{M}$ $\mathrm{KOH}$. The relatively soluble $\mathbf{7 f}$ undergoes rapid hydrolysis to $\mathbf{6} \mathbf{f}$ on refluxing in azeotropic $\mathrm{HCl}$. This method, however, fails for most of the anhydrides 7, which are practically insoluble in $\mathrm{HCl}$.

The structure of $\mathbf{7}$ as cyclic anhydrides of $\mathbf{6}$ is sufficiently demonstrated by the data given. As regards their dimeric composition, the only convincing proof comes from $\mathrm{pH}$-metric titration which points to the absence of low-acidic phosphonate protons and to the presence of ammonium protons of two types with different acidities; the high-acidic phosphonate protons and each type of ammonium protons are in a $2: 1: 1$ ratio.

\section{Experimental}

${ }^{1} \mathrm{H}$ and ${ }^{31} \mathrm{P}$ NMR spectra were obtained with a JEOL FX-90Q or (when necessary) with a Bruker AM-250 spectrometer (for ${ }^{31} \mathrm{P} 36.27$ and 101.25 MHz, respectively). To attain reproducible results, all the ${ }^{31} \mathrm{P}$ NMR spectra were recorded in $\mathrm{D}_{2} \mathrm{O} / \mathrm{H}_{2} \mathrm{O}$ with $\mathrm{Et}_{2} \mathrm{NH}$ buffer at $\mathrm{pH}=10.5-11.5$, reference $-\mathrm{H}_{3} \mathrm{PO}_{4}$, downfield shifts being positive. Small amounts $(5-10 \mathrm{mg})$ of EDTA or CyDTA complexons were introduced into the samples to avoid the broadening of ${ }^{31} \mathrm{P}$ signals by occasional paramagnetic cations.

TLC of $\mathbf{2 , 3}$ (except of lower homologues) and $\mathbf{7}$ was performed on the Silufol ${ }^{\circledR}$ plates in a mixture of $n-\mathrm{C}_{6} \mathrm{H}_{13} \mathrm{OH}$, water, $\mathrm{Et}_{2} \mathrm{NH}$ and Py (equal volumes), spots were detected by spraying with a mixture of water $(50 \mathrm{ml})$, Xylenolorange indicator $(40 \mathrm{mg}), \mathrm{FeCl}_{3} \cdot 6 \mathrm{H}_{2} \mathrm{O}(10 \mathrm{mg})$ and $\mathrm{CCl}_{3} \mathrm{COOH}$ $(0.5 \mathrm{~g})$. For lower 2 and 3 the method [8] (solvent
1) was usually more suitable. The only method found for TLC analysis of $\mathbf{5} \mathbf{a}$ was PC according to Thilo [9] in the acidic solvent C. The melting points were determined only in some cases since this method was found to be inappropriate to characterize the majority of compounds. An additional proof of the oligophosphonate structures was obtained from $\mathrm{pH}$-metric titration, a difference of $<2 \%$ was permitted between the alkali equivalents found and those calculated.

Phosphonylation mixtures of $\mathrm{H}_{3} \mathrm{PO}_{3}$, amine hydrohalides and $\mathrm{PHal}_{3}$ were prepared from the corresponding amounts of conc. aqueous $\mathrm{HHal}$, free amines and $\mathrm{PHal}_{3}$. Caution! To avoid the disproportionation of $\mathrm{H}_{3} \mathrm{PO}_{3}$ and the formation of a pyrophorous yellow polymer with a red phosphorus like structure, it is necessary to maintain the mixtures always strong acidic. An additional organic solvent was added prior to other components to diminish $\mathrm{PHal}_{3}$ loss and self-heating of the reaction mixtures. The phosphorus losses were determined and taken into account in the NMR spectroscopic analysis. Usually, they were within the range $1-12 \%$.

\section{$N$-Dodecylacetoacetamide}

The compound was prepared according to [10], m.p. $86-87^{\circ} \mathrm{C}$.

${ }^{1} \mathrm{H} \mathrm{NMR}\left(\mathrm{CDCl}_{3}\right): \delta 0.83$ [distorted t, $3 \mathrm{H}, \mathrm{CH}_{3}$ (chain), $J=5], 1.21\left[\mathrm{~m}, 20 \mathrm{H}, \mathrm{CH}_{2}\right.$ (chain)], 2.22 (s, $\left.3 \mathrm{H}, \mathrm{CH}_{3} \mathrm{CO}\right), 3.20$ (q, $\left.2 \mathrm{H}, \mathrm{NHC}_{2}, J=6\right), 3.35$ (s, $2 \mathrm{H}, \mathrm{COC}_{2} \mathrm{CO}$ ), 6.95 (br. m, 1H, $\underline{\mathrm{H}}$ ).

\section{1-Methylaminoethylidene-1,1-bis-phosphonic acid} (1a)

A phosphonylation mixture prepared from $\mathrm{PhCl}(7 \mathrm{ml}), 34.4 \%-\mathrm{HCl}(4.56 \mathrm{~g}$ containing $2.99 \mathrm{~g}$, $166.0 \mathrm{mmol}$ of water), Py $(10.6 \mathrm{~g}, 133.9 \mathrm{mmol})$, and $\mathrm{PCl}_{3}(9.34 \mathrm{~g}, 68.0 \mathrm{mmol})$ was saturated with $\mathrm{HCl}$ at $25^{\circ} \mathrm{C}$. N-Methylacetamide $(2.92 \mathrm{~g}$, $40.0 \mathrm{mmol}$ ) was added, the mixture was heated to $75-85^{\circ} \mathrm{C}$, and the second portion of $\mathrm{PCl}_{3}(4.70 \mathrm{~g}$, $34.2 \mathrm{mmol}$ ) was dropped in during $0.5 \mathrm{~h}$ under intensive stirring. After $4 \mathrm{~h}$ stirring at $83-85^{\circ} \mathrm{C}$, water $(40 \mathrm{ml})$ was added, $\mathrm{PhCl}$ was removed by steam distillation simultaneously with the hydrolysis of unstable products at $95-100{ }^{\circ} \mathrm{C}$ for $2 \mathrm{~h}$, the mixture was filtered and analyzed using ${ }^{31} \mathrm{P}$ NMR, the result being $34 \mathrm{mmol}(85 \%)$ of $\mathbf{1 a}$. The filtrate was treated with a cation exchanger of Dowex $-50^{\circledR}$ type $\left(\mathrm{H}^{+}\right.$form $)$, the eluate was evaporated in vacuo, and $\mathrm{MeOH}(45 \mathrm{ml})$ was added to the residue. After overnight standing, the crystals were filtered off, washed with $\mathrm{MeOH}$, and dried, yield $7.52 \mathrm{~g} \mathrm{(83 \% )}$ 
of 1a. The product was reprecipitated from water$\mathrm{Et}_{3} \mathrm{~N}$ with an excess of $\mathrm{HCl}$ and then with $\mathrm{EtOH}$, m.p. $235-240{ }^{\circ} \mathrm{C}$ (decomp.). In [3] no data for 1a are given to be compared.

${ }^{1} \mathrm{H}$ NMR $\left(\mathrm{D}_{2} \mathrm{O}+\mathrm{Na}_{2} \mathrm{CO}_{3}, \mathrm{pH}=6\right): \delta 1.4(\mathrm{t}, 3 \mathrm{H}$, $\left.\mathrm{C}_{3} \mathrm{CP}_{2}, J=14\right), 2.7\left(\mathrm{~s}, 3 \mathrm{H}, \mathrm{NHC}_{3}\right) .{ }^{31} \mathrm{P} \mathrm{NMR}$ : $\delta+12.7(\mathrm{q}, J=14)$.

$$
\mathrm{C}_{3} \mathrm{H}_{11} \mathrm{NO}_{6} \mathrm{P}_{2}(219.1)
$$

Calcd C 16.45

Found C 16.40 H $5.27 \%$.

\section{1-Butylaminoethylidene-1,1-bis-phosphonic acid (1b)}

N-Butylacetamide (4.61 g, $40.0 \mathrm{mmol})$ was subjected to the abovementioned procedure to yield $37 \mathrm{mmol}(92 \%)$ of $\mathbf{1 b}$ according to ${ }^{31} \mathrm{P}$ NMR. After cation exchange, the evaporated eluate was crystallized with $i$-PrOH $(55 \mathrm{ml})$ to give $9.40 \mathrm{~g}$ $(90 \%)$ of $\mathbf{1 b}$. The product was reprecipitated from water with $\mathrm{Me}_{2} \mathrm{CO}$ and dried in vacuo at $90{ }^{\circ} \mathrm{C}$, m.p. $204-206^{\circ} \mathrm{C}$ (decomp.).

${ }^{31} \mathrm{P}$ NMR: $\delta+12.9(\mathrm{q}, J=13)$.

$$
\begin{aligned}
& \mathrm{C}_{6} \mathrm{H}_{17} \mathrm{NO}_{6} \mathrm{P}_{2} \text { (261.2) } \\
& \text { Calcd C } 27.59 \text { H 6.56\%, } \\
& \text { Found C } 27.74 \text { H } 6.67 \% \text {. }
\end{aligned}
$$

\section{1-Cyclohexylaminoethylidene-1,1-bis-phosphonic acid (1c)}

N-Cyclohexylacetamide $(4.24 \mathrm{~g}, 30.0 \mathrm{mmol})$ was added to a phosphonylation mixture prepared from $\mathrm{PhCl}(4 \mathrm{ml}), 34.4 \%-\mathrm{HCl}(4.56 \mathrm{~g}$, containing $2.99 \mathrm{~g}, 166.0 \mathrm{mmol}$ of water $), \mathrm{Bu}_{3} \mathrm{~N}(7.42 \mathrm{~g}$, $40.0 \mathrm{mmol})$ and $\mathrm{PCl}_{3}(9.34 \mathrm{~g}, 68.0 \mathrm{mmol})$. The second portion of $\mathrm{PCl}_{3}(4.70 \mathrm{~g}, 34.2 \mathrm{mmol})$ was added dropwise at $75-80{ }^{\circ} \mathrm{C}$ during $0.5 \mathrm{~h}$. The mixture was stirred at $79-81^{\circ} \mathrm{C}$ for $3.5 \mathrm{~h}$ and, after cooling, hydrolyzed as above with removal of $\mathrm{PhCl}$. A $33 \%-\mathrm{Me}_{2} \mathrm{NH}$ aqueous solution $(50 \mathrm{ml})$ was added to the hydrolyzate, the mixture was extracted with $\mathrm{CHCl}_{3}$, the excess of $\mathrm{Me}_{2} \mathrm{NH}$ was removed from the aqueous layer by concentration in vacuo. The yield of 1c determined by ${ }^{31} \mathrm{P}$ NMR was $24 \mathrm{mmol}$ $(80 \%)$. A treatment similar to that for $\mathbf{1 b}$ gave $6.92 \mathrm{~g}(78 \%)$ of $1 \mathrm{c}$ (purification as for 1a). M.p. 225-227 ${ }^{\circ} \mathrm{C}$ (decomp.).

${ }^{31}$ P NMR: $\delta+12.6(\mathrm{q}, J=13)$.

$$
\begin{aligned}
& \mathrm{C}_{8} \mathrm{H}_{19} \mathrm{NO}_{6} \mathrm{P}_{2} \text { (287.2) } \\
& \text { Calcd C } 33.46 \text { H } 6.67 \% \text {, } \\
& \text { Found C } 33.29 \text { H 6.76\%. }
\end{aligned}
$$

1-Dodecylaminoethylidene-1,1-bis-phosphonic acid (1d)

The reaction components were mixed as in the synthesis of 1c. N-Dodecylacetamide $(6.82 \mathrm{~g}$,
$30 \mathrm{mmol}$ ) was used, $\mathrm{PhCl}$ was replaced by $o-\mathrm{C}_{6} \mathrm{H}_{4} \mathrm{Cl}_{2}(10 \mathrm{ml})$. After $4 \mathrm{~h}$ stirring at $80-82{ }^{\circ} \mathrm{C}$ and subsequent cooling, water $(40 \mathrm{ml})$ was added, the mixture was hydrolyzed at $85-95^{\circ} \mathrm{C}$ for $5 \mathrm{~h}$, then diluted with water $(300 \mathrm{ml})$ and $33 \%-\mathrm{Me}_{2} \mathrm{NH}$ $(150 \mathrm{ml})$. Higher amines and $o-\mathrm{C}_{6} \mathrm{H}_{4} \mathrm{Cl}_{2}$ were extracted with $\mathrm{CHCl}_{3}, \mathrm{MeOH}(150 \mathrm{ml})$ being introduced to accelerate separation of the emulsion. The aqueous layer was concentrated to $200 \mathrm{ml}$ to remove $\mathrm{MeOH}$ and the excess of $\mathrm{Me}_{2} \mathrm{NH}$. According to ${ }^{31} \mathrm{P} \mathrm{NMR}$, the solution contained $27 \mathrm{mmol}$ $(90 \%)$ of 1d. It was acidified with $35 \%-\mathrm{HCl}$ $(80 \mathrm{ml})$, the suspension was refluxed for $c a .1 \mathrm{~min}$ and allowed to stand overnight. The crystals were filtered off, washed with $5 \%-\mathrm{HCl}$, water and $\mathrm{Me}_{2} \mathrm{CO}$ to yield after drying $9.75 \mathrm{~g}(87 \%)$ of $\mathbf{1 d}$. The product was recrystallized from EtOH conc. $\mathrm{HCl}$ ( $20: 1$ by volume), dried in vacuo at $90{ }^{\circ} \mathrm{C}$, and kept over a saturated $\mathrm{NaCl}$ solution to give 1d monohydrate, m.p. $207-209^{\circ} \mathrm{C}$ (decomp.).

${ }^{31}$ P NMR: $\delta+12.8(\mathrm{q}, J=13)$.

$$
\begin{aligned}
& \mathrm{C}_{14} \mathrm{H}_{35} \mathrm{NO}_{7} \mathrm{P}_{2} \text { (391.4) } \\
& \text { Calcd C } 42.96 \text { H 9.01\%, } \\
& \text { Found C } 43.14 \text { H 9.16\%. }
\end{aligned}
$$

\section{1-Benzylaminoethylidene-1,1-bis-phosphonic acid} (1e)

The phosphonylation mixture was prepared as for the synthesis of $\mathbf{1 a}, \mathrm{PhCl}$ being replaced by $o-\mathrm{C}_{6} \mathrm{H}_{4} \mathrm{Cl}_{2} \quad(8 \mathrm{ml})$. N-Benzylacetamide $(4.48 \mathrm{~g}$, $30.0 \mathrm{mmol}$ ) was added, the second portion of $\mathrm{PCl}_{3}$ $(4.70 \mathrm{~g}, 34.2 \mathrm{mmol})$ was added dropwise at $75-80{ }^{\circ} \mathrm{C}$ during $0.5 \mathrm{~h}$, and the mixture was stirred at $79-81{ }^{\circ} \mathrm{C}$ for $4 \mathrm{~h}$. After cooling, the mixture was hydrolyzed as in the synthesis of 1a with removal of $o-\mathrm{C}_{6} \mathrm{H}_{4} \mathrm{Cl}_{2}$. The crystals of $1 \mathrm{e}$ were dissolved by addition of $\mathrm{Et}_{2} \mathrm{NH}(45 \mathrm{ml})$, the solution was evaporated in vacuo. The residue was diluted with water and filtered through Polyamide Woelm $T L C^{\circledR}$. According to ${ }^{31} \mathrm{P} \mathrm{NMR}$, the filtrate contained $22.5 \mathrm{mmol}(75 \%)$ of 1e. A treatment similar to that for $1 \mathrm{~b}$ yielded $6.59 \mathrm{~g}(74 \%)$ of $1 \mathrm{e}$, which was purified analogously to 1a, m. p. $232-235^{\circ} \mathrm{C}$ (decomp.).

${ }^{1} \mathrm{H}$ NMR $\left(\mathrm{D}_{2} \mathrm{O}+\mathrm{Na}_{2} \mathrm{CO}_{3}, \mathrm{pH}=7\right): \delta 1.6(\mathrm{t}, 3 \mathrm{H}$, $\left.\mathrm{C}_{3}, J=13\right), 4.4\left(\mathrm{~s}, 2 \mathrm{H}, \underline{\mathrm{C}}_{2}\right), 7.4\left(\mathrm{~s}, 5 \mathrm{H}, \mathrm{C}_{6} \underline{\mathrm{H}}_{5}\right)$. ${ }^{31}$ P NMR: $\delta+14.6(\mathrm{q}, J=13)$.

$$
\begin{aligned}
& \mathrm{C}_{9} \mathrm{H}_{15} \mathrm{NO}_{6} \mathrm{P}_{2} \text { (295.2) } \\
& \text { Calcd C } 36.62 \text { H } 5.12 \% \text {, } \\
& \text { Found C } 36.56 \text { H } 5.31 \% \text {. }
\end{aligned}
$$


Bicyclic 1-cyclohexylaminobutane-1,1,3,3-tetrayltetrakis-phosphonic anhydride $\mathbf{( 2 \mathbf { c } )}$

$\mathrm{N}$-Cyclohexylacetamide $\quad(5.65 \mathrm{~g}, \quad 40.0 \mathrm{mmol})$ was added to the phosphonylation mixture similar to that for the synthesis of $1 \mathbf{a}$, the second $\mathrm{PCl}_{3}$ portion $(4.70 \mathrm{~g}, 34.2 \mathrm{mmol})$ was dropped in at $75-80{ }^{\circ} \mathrm{C}$ during $0.5 \mathrm{~h}$, the mixture was stirred at $82-84{ }^{\circ} \mathrm{C}$ for $6 \mathrm{~h}$, and allowed to cool to $25^{\circ} \mathrm{C}$. Water $(150 \mathrm{ml})$ was added, the mixture was immediately neutralized with $\mathrm{Et}_{2} \mathrm{NH}(50 \mathrm{ml})$. $\mathrm{PhCl}$, Py and excess of $\mathrm{Et}_{2} \mathrm{NH}$ were removed by evaporation in vacuo. The residue was dissolved in water and filtered. The ${ }^{31} \mathrm{P}$ NMR analysis detected $18.4 \mathrm{mmol}(92 \%)$ of 2 c. The filtrate $(68 \mathrm{~g})$ was cooled to $0{ }^{\circ} \mathrm{C}$, acidified with cold $35 \%-\mathrm{HCl}$ $(29 \mathrm{ml})$, diluted with $i$-PrOH $(125 \mathrm{ml})$ and allowed to stand at $0{ }^{\circ} \mathrm{C}$ for crystallization, yielding $8.73 \mathrm{~g}$ $(81 \%)$ of $2 \mathrm{c}$ solvate with $i$-PrOH $(\mathrm{M}=536.0$ according to $\mathrm{pH}$-metric titration). The product was dissolved in a minimum amount of water, the solution was concentrated in vacuo to $1 / 4$ of the initial volume. The precipitate was filtered off, washed with small portions of water and air-dried to give $2 \mathrm{c}$ trihydrate.

$$
\begin{aligned}
& \mathrm{C}_{10} \mathrm{H}_{27} \mathrm{NO}_{13} \mathrm{P}_{4} \text { (493.2) } \\
& \text { Calcd C } 24.35 \text { H } 5.52 \% \text {, } \\
& \text { Found C } 24.23 \text { H } 5.53 \% \text {. }
\end{aligned}
$$

Monocyclic 1-methylaminobutane-1,1,3,3-tetrayltetrakis-phosphonic anhydride (3a)

$\mathrm{N}$-Methylacetamide $(2.92 \mathrm{~g}, 40.0 \mathrm{mmol})$ was introduced into the reaction as in the synthesis of $\mathbf{1 a}$. The second portion of $\mathrm{PCl}_{3}(4.70 \mathrm{~g}, 34.2 \mathrm{mmol})$ was added at $80-93{ }^{\circ} \mathrm{C}$ during $0.5 \mathrm{~h}$. The mixture was stirred at $91-93^{\circ} \mathrm{C}$ for $9.5 \mathrm{~h}$, hydrolyzed with water $(40 \mathrm{ml})$ at $90-97^{\circ} \mathrm{C}$ for $1.5 \mathrm{~h}$, with $\mathrm{PhCl}$ being removed, and filtered. The ${ }^{31} \mathrm{P}$ NMR spectroscopic analysis detected $18.2 \mathrm{mmol}(91 \%)$ of $\mathbf{3 a}$ and $1.4 \mathrm{mmol}(7 \%)$ of $\mathbf{4 a}$. The filtrate was evaporated in vacuo up to the end of distillation (bath up to $80^{\circ} \mathrm{C}$ ). The residue was dissolved in $\mathrm{MeOH}$ $(50 \mathrm{ml})$ at $50-60{ }^{\circ} \mathrm{C}$, the crystallization being initiated by rubbing. After continuous standing at $20-25^{\circ} \mathrm{C}$, the crystals were filtered off, washed with $\mathrm{MeOH}$ and dried to yield $7.84 \mathrm{~g}(84 \%)$ of $3 \mathrm{a}$ monopyridinium salt. The product was reprecipitated from water with $\mathrm{Me}_{2} \mathrm{CO}$ and dried in vacuo at $50-55^{\circ} \mathrm{C}$.

${ }^{1} \mathrm{H}$ NMR $\left(\mathrm{D}_{2} \mathrm{O}\right): \delta 1.3\left(\mathrm{t}, 3 \mathrm{H}, \mathrm{CH}_{3} \mathrm{C}, J=15\right)$, 1.8-2.8 (br. m, $2 \mathrm{H}, \mathrm{CH}_{2}$ ), 2.8 (s, $3 \mathrm{H}, \mathrm{NHCH}_{3}$ ), $7.8-8.6(\mathrm{~m}, 5 \mathrm{H}$, pyridinium $\mathrm{H})$.

${ }^{13} \mathrm{C} \mathrm{NMR}\left(75.47 \mathrm{MHz}, \mathrm{D}_{2} \mathrm{O}\right): \delta 24.5\left(\mathrm{t}, \mathrm{CH}_{3} \mathrm{CP}_{2}\right.$, $J=4), 33.8\left(\mathrm{NHCH}_{3}\right), 40.7$ (t with small additional couplings, $\left.\mathrm{CH}_{3} \underline{\mathrm{CP}}{ }_{2}, J=112\right), 43.0\left(\underline{\mathrm{CH}}_{2}\right), 63.6$ (dd, $\mathrm{NHCP}_{2}, J_{1}=125, J_{2}=111$ ), 127.2 (pyridinium 3-C), 140.2 (pyridinium 4-C), 151.5 (pyridinium $2-\underline{C}$ ).

$$
\begin{array}{rrrrrr}
\mathrm{C}_{10} \mathrm{H}_{20} \mathrm{~N}_{2} \mathrm{O}_{11} \mathrm{P}_{4}(468.2) & & & \\
\text { Calcd } & \mathrm{C} 25.65 & \mathrm{H} 4.31 & \mathrm{~N} 5.98 & \mathrm{P} 26.5 \%, \\
\text { Found } & \mathrm{C} 25.39 & \mathrm{H} 4.39 & \mathrm{~N} 5.82 & \mathrm{P} 25.9 \% .
\end{array}
$$

Monocyclic 1-butylaminobutane-1,1,3,3-tetrayltetrakis-phosphonic anhydride (3b)

The phosphonylation of N-butylacetamide (4.61 g, $40.0 \mathrm{mmol}$ ) and the hydrolysis of the reaction mixture were carried out the same as in the synthesis of 3a. The ${ }^{31} \mathrm{P}$ NMR spectroscopic analysis detected $15.7 \mathrm{mmol}(78 \%)$ of $\mathbf{3 b}$ and $2.6 \mathrm{mmol}$ $(13 \%)$ of $\mathbf{4} \mathbf{b}$. The filtrate was treated with a cation exchanger, the eluate was evaporated in vacuo (bath up to $70^{\circ} \mathrm{C}$ ), the residue was dissolved in EtOH $(60 \mathrm{ml})$. The crystallization was complete only after continuous standing at $20-25^{\circ} \mathrm{C}$, yielding $6.98 \mathrm{~g}(72 \%)$ of $\mathbf{3} \mathbf{b}$ trihydrate. The product was reprecipitated from water with $\mathrm{Me}_{2} \mathrm{CO}$ and dried in vacuo at $40-50{ }^{\circ} \mathrm{C}$.

$$
\begin{array}{ccc}
\mathrm{C}_{8} \mathrm{H}_{27} \mathrm{NO}_{14} \mathrm{P}_{4}(485.2) & \\
\text { Calcd } & \mathrm{C} 19.80 & \text { H } 5.61 \%, \\
\text { Found } & \text { C } 19.79 & \text { H } 5.80 \% .
\end{array}
$$
Monocyclic 1-benzylaminobutane-1,1,3,3-tetrayl-
tetrakis-phosphonic anhydride (3e)

The reaction of $\mathrm{N}$-benzylacetamide $(5.97 \mathrm{~g}$, $40.0 \mathrm{mmol}$ ) was carried out similarly to that in the synthesis of $\mathbf{3 a}$. According to ${ }^{31} \mathrm{P} \mathrm{NMR}$, $16.6 \mathrm{mmol}(83 \%)$ of $3 \mathbf{e}$ and $2.4 \mathrm{mmol}(12 \%)$ of $4 \mathbf{e}$ were obtained. The isolation (analogous to that for $\mathbf{3 b}$ ) yielded $7.02 \mathrm{~g}(67 \%)$ of $\mathbf{3 e}$ solvate with EtOH (by ${ }^{1} \mathrm{H}$ NMR, EtOH: $3 \mathbf{e}=0.6$; according to $\mathrm{pH}$-metric titration, $\mathrm{M}=522.0$ ). The product was reprecipitated from water with $\mathrm{EtOH}$, then dissolved in water, and slowly dried up to the crystallization, giving $3 \mathbf{e}$ trihydrate.

${ }^{1} \mathrm{H}$ NMR $\left(\mathrm{D}_{2} \mathrm{O}+\mathrm{Na}_{2} \mathrm{CO}_{3}, \mathrm{pH}=9\right): \delta 1.3(\mathrm{dd}$, $3 \mathrm{H}, \mathrm{CH}_{3}, J_{1}=16, J_{2}=13$ ), $2.0-3.0$ (br. $\mathrm{m}, 2 \mathrm{H}$, $\mathrm{CP}_{2} \mathrm{CH}_{2} \mathrm{CP}_{2}$ ), 4.7 and 5.0 (two d, $1 \mathrm{H}$ and $1 \mathrm{H}$, diastereotopic $\mathrm{NHCH}_{2}$ protons, $\left.J=13\right), 7.4-7.7(\mathrm{~m}$, $\left.5 \mathrm{H}, \mathrm{C}_{6} \underline{\mathrm{H}}_{5}\right)$.

$$
\begin{array}{ccc}
\mathrm{C}_{11} \mathrm{H}_{25} \mathrm{NO}_{14} \mathrm{P}_{4}(519.2) & \\
\text { Calcd } & \mathrm{C} 25.45 & \mathrm{H} 4.85 \%, \\
\text { Found } & \mathrm{C} 25.22 & \mathrm{H} 4.79 \% .
\end{array}
$$

Bicyclic (2d) and monocyclic (3d) 1-dodecylaminobutane-1,1,3,3-tetrayl-tetrakis-phosphonic anhydrides

$\mathrm{N}$-Dodecylacetamide $(9.09 \mathrm{~g}, 40.0 \mathrm{mmol})$ was added to the phosphonylation mixture prepared 
similarly to that for the synthesis of $\mathbf{1 a}$. The second portion of $\mathrm{PCl}_{3}(4.70 \mathrm{~g}, 34.2 \mathrm{mmol})$ was added dropwise at $80-96{ }^{\circ} \mathrm{C}$ during $0.5 \mathrm{~h}$. The frothy mixture was stirred at $94-96^{\circ} \mathrm{C}$ for $10 \mathrm{~h}$ and allowed to cool to $25^{\circ} \mathrm{C}$. The reaction mass was suspended in water $(200 \mathrm{ml})$ and $\mathrm{CHCl}_{3}(450 \mathrm{ml})$, $33 \%-\mathrm{Me}_{2} \mathrm{NH}(250 \mathrm{ml})$ was added, the aqueous layer was separated and additionally extracted with $\mathrm{CHCl}_{3}$. The excess of $\mathrm{Me}_{2} \mathrm{NH}$ was removed by concentration in vacuo. According to ${ }^{31} \mathrm{P} \mathrm{NMR}$, the solution contained $20 \mathrm{mmol}(100 \%)$ of $\mathbf{2} \mathbf{d}$.

To isolate $\mathbf{2 d}$, the solution ( $172 \mathrm{~g}$ ) was cooled to $10{ }^{\circ} \mathrm{C}$, acidified with $35 \%-\mathrm{HCl}(172 \mathrm{ml})$, and allowed to stand at $15-20{ }^{\circ} \mathrm{C}$ for $0.5 \mathrm{~h}$. The voluminous precipitate was filtered off, washed with $18 \%-\mathrm{HCl}$, then with $\mathrm{Et}_{2} \mathrm{O}$, and dried over $\mathrm{KOH}$ to remove the rest of $\mathrm{HCl}$ and water. The cake was suspended in $\mathrm{Me}_{2} \mathrm{CO}$ to give $10.14 \mathrm{~g}(93 \%)$ of $\mathbf{2 d}$ monohydrate after filtration. The product was reprecipitated from a mixture $i$ - $\mathrm{PrOH}$-water$\mathrm{CF}_{3} \mathrm{COOH}$ (14:2.7:0.7 by volume) with EtOAc and dried in vacuo at $70-80{ }^{\circ} \mathrm{C}$.

$$
\begin{aligned}
& \mathrm{C}_{16} \mathrm{H}_{37} \mathrm{NO}_{11} \mathrm{P}_{4} \text { (543.4) } \\
& \text { Calcd C } 35.37 \text { H } 6.86 \% \text {, } \\
& \text { Found C } 35.50 \text { H } 6.81 \% \text {. }
\end{aligned}
$$

To isolate $\mathbf{3 d}$, the solution was diluted with water to 1.51 and treated with a cation exchanger. The eluate (1.9 l) was hydrolyzed at $100{ }^{\circ} \mathrm{C}$ for $3.5 \mathrm{~h}$ (attaining the full conversion of $\mathbf{2} \mathbf{d}$ into $\mathbf{3 d}$ ) and concentrated to $149 \mathrm{~g}$. After addition of $36 \%$ $\mathrm{HCl}(86 \mathrm{ml})$, the mixture was allowed to stand at $20-25{ }^{\circ} \mathrm{C}$ for several days. The crystals were filtered off and washed as in the isolation of $\mathbf{2} \mathbf{d}$. The product was dried in vacuo at $50-55^{\circ} \mathrm{C}$ and kept over a saturated $\mathrm{NaCl}$ solution to yield $10.49 \mathrm{~g}$ $(88 \%)$ of $\mathbf{3 d}$ trihydrate.

$$
\begin{aligned}
& \mathrm{C}_{16} \mathrm{H}_{43} \mathrm{NO}_{14} \mathrm{P}_{4} \text { (597.4) } \\
& \text { Calcd C } 32.16 \text { H 7.27\%, } \\
& \text { Found C } 32.20 \text { H 7.38\%. }
\end{aligned}
$$

\section{Phosphonylation of $\mathrm{N}$-dodecylacetoacetamide}

$\mathrm{N}$-Dodecylacetoacetamide $(5.39 \mathrm{~g}, 20.0 \mathrm{mmol})$ was added at $25^{\circ} \mathrm{C}$ to a phosphonylation mixture prepared from $\mathrm{PhCl}(7 \mathrm{ml}), 34.4 \%-\mathrm{HCl}(4.56 \mathrm{~g}$ containing $2.99 \mathrm{~g}, 166.0 \mathrm{mmol}$ of water), Py $(6.87 \mathrm{~g}, 86.8 \mathrm{mmol})$ and $\mathrm{PCl}_{3}(9.34 \mathrm{~g}, 68.0 \mathrm{mmol})$. The second portion of $\mathrm{PCl}_{3}(4.70 \mathrm{~g}, 34.2 \mathrm{mmol})$ was added dropwise at $85-92{ }^{\circ} \mathrm{C}$ during $15 \mathrm{~min}$ and the mixture was stirred at $91-93^{\circ} \mathrm{C}$ for $6 \mathrm{~h}$. After cooling, the reaction mass was suspended in water $(200 \mathrm{ml})$, mixed with $33 \%-\mathrm{Me}_{2} \mathrm{NH}(250 \mathrm{ml})$, and extracted with $\mathrm{CHCl}_{3}$. The aqueous layer was concentrated in vacuo to remove excess $\mathrm{Me}_{2} \mathrm{NH}$ and analyzed by ${ }^{31} \mathrm{P}$ NMR, the yield being $18.4 \mathrm{mmol}(92 \%)$ of $\mathbf{2 d}$. The product was isolated as mentioned above.

\section{Bicyclic 1-butylaminodecane-1,1,3,3-tetrayl- tetrakis-phosphonic anhydride (2f)}

The phosphonylation mixture was prepared as in the synthesis of $1 \mathrm{a}, \mathrm{PhCl}$ being replaced with $o-\mathrm{C}_{6} \mathrm{H}_{4} \mathrm{Cl}_{2} \quad(7 \mathrm{ml})$. N-Butylacetamide $\quad(2.31 \mathrm{~g}$, $20.0 \mathrm{mmol}$ ) and N-caprylylpyrrolidine (3.95 g, $20.0 \mathrm{mmol}$ ) were added simultaneously, the second portion of $\mathrm{PCl}_{3}(4.70 \mathrm{~g}, 34.2 \mathrm{mmol})$ at $75-82^{\circ} \mathrm{C}$ during $20 \mathrm{~min}$. The reaction mixture was stirred at $81-82{ }^{\circ} \mathrm{C}$ for $4 \mathrm{~h}$, then at $91-92{ }^{\circ} \mathrm{C}$ for $6 \mathrm{~h}$, and allowed to cool to $25^{\circ} \mathrm{C}$. Water $(200 \mathrm{ml})$ and $33 \%$ $\mathrm{Me}_{2} \mathrm{NH}(150 \mathrm{ml})$ were added, the emulsion was extracted with $\mathrm{CHCl}_{3}$. The aqueous layer was concentrated in vacuo to remove excess $\mathrm{Me}_{2} \mathrm{NH}$ and analyzed by ${ }^{31} \mathrm{P}$ NMR, showing $14.6 \mathrm{mmol}(73 \%)$ of $\mathbf{2 f}$ and $1.0 \mathrm{mmol}(10 \%$ calculated on N-butylacetamide) of $\mathbf{2} \mathbf{b}$. To the solution $(83 \mathrm{~g})$ a mixture of $\mathrm{PhNH}_{2}(36 \mathrm{ml})$, water $(72 \mathrm{ml})$ and $35 \%-\mathrm{HCl}(26 \mathrm{ml})$ was added at $40-45^{\circ} \mathrm{C}$, and the suspension was allowed to stand overnight. The precipitate was filtered off and washed portionwise with a mixture of $\mathrm{PhNH}_{2}(16 \mathrm{ml})$, water $(25 \mathrm{ml})$ and $35 \%-\mathrm{HCl}(10 \mathrm{ml})$. The cake was suspended in a mixture of $i-\mathrm{PrOH}(50 \mathrm{ml})$ and $\mathrm{PhNH}_{2}$ $(1 \mathrm{ml})$, filtered off and washed with $i-\mathrm{PrOH}$ to give $10.99 \mathrm{~g}$ of crude $\mathbf{2 f}$ aniline salt, which was dissolved in a hot mixture of $i-\mathrm{PrOH}(160 \mathrm{ml})$, water $(75 \mathrm{ml})$ and $\mathrm{PhNH}_{2}(25 \mathrm{ml})$. After cooling to $50-60{ }^{\circ} \mathrm{C}$, the solution was acidified with $35 \%$ $\mathrm{HCl}(26 \mathrm{ml})$ and allowed to stand overnight at $20-25{ }^{\circ} \mathrm{C}$ for crystallization, to yield $7.63 \mathrm{~g}(53 \%)$ of pure $2 \mathbf{f}$ aniline salt with the molar ratio 2f: $\mathrm{PhNH}_{2}$ close to $1: 2(\mathrm{M}=715.6$ according to $\mathrm{pH}$-metric titration). The product was recrystallized from EtOH-water- $\mathrm{PhNH}_{2} \quad(20: 4: 1$ by volume), dried in vacuo at $110{ }^{\circ} \mathrm{C}$ to attain the equimolar $2 \mathbf{f}: \mathrm{PhNH}_{2}$ ratio and kept over a saturated $\mathrm{NaCl}$ solution, giving $2 \mathbf{f}$ monoaniline salt trihydrate.

${ }^{1} \mathrm{H}$ NMR $\left(\mathrm{D}_{2} \mathrm{O}+\mathrm{Na}_{2} \mathrm{CO}_{3}, \mathrm{pH}=8\right): \delta 0.9$ [distorted t, $3 \mathrm{H}, \mathrm{CH}_{3}$ (heptyl chain), $\left.J=6\right], 1.0[\mathrm{t}, 3 \mathrm{H}$, $\mathrm{CH}_{3}$ (butyl chain), $\left.J=6\right], 1.2-1.8\left[\mathrm{~m}, 16 \mathrm{H}, \mathrm{CH}_{2}\right.$ (aliphatic)], $1.9-2.9$ (br. m, $2 \mathrm{H}, \mathrm{CP}_{2} \mathrm{CH}_{2} \mathrm{CP}_{2}$ ), 3.4 $\left(\mathrm{t}, 2 \mathrm{H}, \mathrm{NHC}_{2}, J=7\right), 6.8-7.4\left(\mathrm{~m}, 5 \mathrm{H}, \mathrm{C}_{6} \underline{\mathrm{H}}_{5}\right)$.

$$
\begin{aligned}
& \mathrm{C}_{20} \mathrm{H}_{44} \mathrm{~N}_{2} \mathrm{O}_{13} \mathrm{P}_{4} \text { (644.5) } \\
& \text { Calcd C } 37.27 \\
& \text { Found C } 37.07 \\
& \mathrm{H} 6.88 \% \text {, } \\
& \text { H } 7.12 \% \text {. }
\end{aligned}
$$


Bicyclic 1-butylaminotetradecane-1,1,3,3-tetrayltetrakis-phosphonic anhydride $\mathbf{( 2 \mathbf { g } )}$

The cross-phosphonylation of N-butylacetamide $(2.31 \mathrm{~g}, \quad 20.0 \mathrm{mmol})$ with N-laurylpyrrolidine $(5.07 \mathrm{~g}, 20.0 \mathrm{mmol})$ was carried out, and the solution of $\mathrm{Me}_{2} \mathrm{NH}$ salts was obtained according to the procedure used for $\mathbf{2 f}$. ${ }^{31} \mathrm{P}$ NMR showed $13.2 \mathrm{mmol}(66 \%)$ of $\mathbf{2} \mathrm{g}$ and $1.9 \mathrm{mmol}(19 \%$ on N-butylacetamide) of $\mathbf{2} \mathbf{b}$. To the solution $(110 \mathrm{~g})$ a mixture of water $(105 \mathrm{ml}), \mathrm{PhNH}_{2}(47 \mathrm{ml})$ and $35 \%-\mathrm{HCl}(41 \mathrm{ml})$ was added, the suspension was allowed to stand for a day at $20-25^{\circ} \mathrm{C}$. The precipitate was filtered off, washed portionwise with a mixture of water $(150 \mathrm{ml}), \mathrm{PhNH}_{2}(30 \mathrm{ml})$ and $35 \%-\mathrm{HCl}(26 \mathrm{ml})$, then with water and $\mathrm{Et}_{2} \mathrm{O}$ to give $12.66 \mathrm{~g}$ of crude $2 \mathrm{~g}$ aniline salt. The product was refluxed for $1 \mathrm{~h}$ with a mixture of $i-\mathrm{PrOH}$ $(217 \mathrm{ml})$, water $(43 \mathrm{ml})$ and $\mathrm{PhNH}_{2}(14 \mathrm{ml})$, then hot-filtered to remove any insoluble impurity. The filtrate was acidified with $\mathrm{CF}_{3} \mathrm{COOH}(15 \mathrm{ml})$ and allowed to stand for 2 days. The crystals were filtered off and washed with $i$-PrOH to yield $6.92 \mathrm{~g}$ $(44 \%)$ of pure $2 \mathrm{~g}$ aniline salt (non-stoichiometric, $\mathrm{M}=780$ according to $\mathrm{pH}$-metric titration). The product was recrystallized from $i$-PrOH-water $(6: 1$ by volume), dried in vacuo at $110{ }^{\circ} \mathrm{C}$, and kept over a saturated $\mathrm{NaCl}$ solution, giving $\mathbf{2}$ g monoaniline salt dihydrate.

$$
\begin{aligned}
& \mathrm{C}_{24} \mathrm{H}_{50} \mathrm{~N}_{2} \mathrm{O}_{12} \mathrm{P}_{4} \text { (682.6) } \\
& \text { Calcd C } 42.23 \\
& \text { Found C } 42.05 \text { H 7.16\%. }
\end{aligned}
$$

tion of the product $(0.50 \mathrm{~g}, 4 \%)$ was obtained from the concentrated $\mathrm{HCl}$-water filtrate. The product was purified using a procedure analogous to that for $\mathbf{2} \mathbf{c}$.

$$
\begin{array}{ccc}
\mathrm{C}_{17} \mathrm{H}_{37} \mathrm{NO}_{14} \mathrm{P}_{4}(603.4) & \\
\text { Calcd } & \mathrm{C} 33.84 & \mathrm{H} 6.18 \%, \\
\text { Found } & \mathrm{C} 33.85 & \text { H } 6.54 \% .
\end{array}
$$

\section{3,3-Diphosphonobutyric acid (5a)}

Unpurified 2c solvate with $i$-PrOH $(5.00 \mathrm{~g}$, $9.33 \mathrm{mmol})$ was refluxed with azeotropic $\mathrm{HCl}$ $(70 \mathrm{ml})$ for $6.5 \mathrm{~h}$ to yield $97 \%$ of $\mathbf{5 a}$ according to ${ }^{31} \mathrm{P}$ NMR. The hydrolyzate was evaporated in vacuo to remove water and $\mathrm{HCl}$ as fully as possible (bath up to $85^{\circ} \mathrm{C}$ ). After partial crystallization, the residue was treated with $\mathrm{Et}_{2} \mathrm{O}(100 \mathrm{ml})$ and allowed to stand for several days with periodic stirring. The precipitate was filtered off, washed with $\mathrm{Et}_{2} \mathrm{O}$, and suspended in $i$-PrOH $(35 \mathrm{ml})$ to yield, after standing up to the end of crystallization, $3.12 \mathrm{~g}(96 \%)$ of $\mathbf{5 a}$ cyclohexylammonium salt. The product was reprecipitated from water with $\mathrm{Me}_{2} \mathrm{CO}$, dried in vacuo at $70^{\circ} \mathrm{C}$, and kept over a saturated $\mathrm{NaCl}$ solution, giving a monohydrate, m.p. $136-138^{\circ} \mathrm{C}$.

${ }^{1} \mathrm{H}$ NMR $\left(\mathrm{D}_{2} \mathrm{O}, \mathrm{NH}_{4}\right.$-salt, $\mathrm{pH}=6$, cyclohexylamine removed): $\delta 1.1\left(\mathrm{t}, 3 \mathrm{H}, \underline{\mathrm{CH}}_{3}, J=15\right), 2.4$ (t, $\left.2 \mathrm{H}, \underline{\mathrm{CH}}_{2}, J=15\right)$.

$$
\begin{array}{rrr}
\mathrm{C}_{10} \mathrm{H}_{25} \mathrm{NO}_{9} \mathrm{P}_{2} & (365.3) & \\
\text { Calcd } & \mathrm{C} 32.88 & \text { H } 6.90 \%, \\
\text { Found } & \text { C } 33.04 & \text { H } 6.92 \% .
\end{array}
$$

\section{Monocyclic 1-benzylaminodecane-1,1,3,3-tetrayl- tetrakis-phosphonic anhydride (3h)}

The cross-phosphonylation of N-benzylacetamide $(2.99 \mathrm{~g}, 20.0 \mathrm{mmol})$ with $\mathrm{N}$-caprylylpyrrolidine $(3.95 \mathrm{~g}, 20.0 \mathrm{mmol})$ was carried out as in the synthesis of $\mathbf{2} \mathbf{f}$, the time of stirring at $91-92{ }^{\circ} \mathrm{C}$ being reduced to $4 \mathrm{~h}$. The solution of $\mathrm{Me}_{2} \mathrm{NH}$ salts was obtained as above and analyzed by ${ }^{31} \mathrm{P}$ NMR, which detected $15.4 \mathrm{mmol}(77 \%)$ of $\mathbf{2 h}$ and $1.2 \mathrm{mmol}(12 \%$ on N-benzylacetamide) of $2 \mathrm{e}$. The mixture was diluted with water to 0.51 and treated with a cation exchanger. The eluate was evaporated in vacuo, and the residue refluxed with water $(250 \mathrm{ml})$ for $15 \mathrm{~h}$ up to the complete conversion of $\mathbf{2 h}$ into $\mathbf{3 h}$. After cooling, the solution was filtered, concentrated to $168 \mathrm{~g}$ and mixed with $35 \%-\mathrm{HCl}$ $(210 \mathrm{ml})$. The mixture was allowed to stand for 3 days with periodic stirring. The precipitate was filtered off, washed with $18 \%-\mathrm{HCl}$ and with hexane, air-dried, and finally washed with $\mathrm{Me}_{2} \mathrm{CO}$ to give $5.90 \mathrm{~g}(49 \%)$ of $\mathbf{3 h}$ trihydrate. An additional por-

\section{Phosphonylation of $\mathrm{N}$-alkylamides to $\mathbf{6}$ and 7}

N-Alkylamide $(40.0 \mathrm{mmol})$ was added to the phosphonylation mixture prepared as for the reaction of N-dodecylacetoacetamide. The second portion of $\mathrm{PCl}_{3}(4.70 \mathrm{~g}, 34.2 \mathrm{mmol})$ was added dropwise at $75-87^{\circ} \mathrm{C}$ during $15-30 \mathrm{~min}$. The mixture was stirred at $87-89^{\circ} \mathrm{C}$ for $2 \mathrm{~h}$, diluted with water $(50-250 \mathrm{ml})$, and hydrolyzed at $90-98^{\circ} \mathrm{C}$ for $2 \mathrm{~h}$, with $\mathrm{PhCl}$ being removed. The precipitate was dissolved by addition of a suitable amine, the solulauramide was phosphonylated, the precipitate was filtered off, washed with $5 \%-\mathrm{HCl}$, water, $\mathrm{Me}_{2} \mathrm{CO}$, and analyzed separately. Yields and ${ }^{31} \mathrm{P}$ NMR data for 6,7 are given in Table V.

\section{Cyclic dimeric 1-methylaminopropylidene- 1,1-bis-phosphonic anhydride (7a)}

The phosphonylation of N-methylpropionamide (3.48 g, $40.0 \mathrm{mmol}$ ) was carried out as above, Py tion was analyzed by ${ }^{31} \mathrm{P}$ NMR. When N-methyl- 
$(40 \mathrm{ml})$ being added to dissolve the precipitate of 7 a. The filtered solution $(335 \mathrm{~g})$ was acidified with $35 \%-\mathrm{HCl}(205 \mathrm{ml})$ at $70-80{ }^{\circ} \mathrm{C}$ and allowed to stand overnight. The precipitate was filtered off, washed with $10 \%-\mathrm{HCl}, \mathrm{EtOH}$ and $\mathrm{Me}_{2} \mathrm{CO}$ to give crude $7 \mathrm{a}$ hydrate $(7.69 \mathrm{~g})$, which contained as the only impurity $(4 \%)$ the supposed minor isomer. The product was dissolved in water with an excess of $\mathrm{MeNH}_{2}$, and the solution was concentrated in vacuo to $25.5 \mathrm{~g}$. The precipitate was filtered off, washed with small portions of water (total amount $4.5 \mathrm{ml}$ ) and with $\mathrm{Me}_{2} \mathrm{CO}$ to give $7.59 \mathrm{~g}$ of the pure 7a $\mathrm{MeNH}_{2}$ salt. It was dissolved in water $(85 \mathrm{ml})$, the solution was acidified with $35 \%-\mathrm{HCl}(26 \mathrm{ml})$, the suspension was heated on a steam bath for $0.5 \mathrm{~h}$ and allowed to cool to $20-25^{\circ} \mathrm{C}$. The precipitate was filtered off, washed with $5 \%-\mathrm{HCl}$ and with $\mathrm{Me}_{2} \mathrm{CO}$, dried in vacuo at $50-60{ }^{\circ} \mathrm{C}$, and kept over a saturated $\mathrm{NaCl}$ solution, to yield $6.01 \mathrm{~g}$ $(62 \%)$ of 7 a trihydrate.

${ }^{1} \mathrm{H}$ NMR $\left(\mathrm{D}_{2} \mathrm{O}+\mathrm{Py}\right): \delta 1.0\left(\mathrm{t}, 3 \mathrm{H}, \mathrm{CH}_{3} \mathrm{CH}_{2}\right.$, $J=7), 1.7-2.3\left(\mathrm{~m}, 2 \mathrm{H}, \mathrm{CH}_{2}\right), 2.7(\mathrm{~s}, 3 \mathrm{H}$, $\left.\mathrm{NHC}_{3}\right)$.

${ }^{13} \mathrm{C} \quad \mathrm{NMR} \quad\left(50.31 \mathrm{MHz}, \quad \mathrm{D}_{2} \mathrm{O}+\mathrm{Py}\right): \quad \delta 8.2$ $\left(\mathrm{CH}_{3} \mathrm{CH}_{2}\right), 20.4\left(\underline{\mathrm{CH}}_{2}\right), 28.9\left(\mathrm{NH}^{\mathrm{C}} \mathrm{H}_{3}\right), 63.4$ (additionally coupled $\left.\mathrm{t}, \underline{\mathrm{CP}}_{2}, J=139\right)$.

$$
\begin{array}{ccccc}
\mathrm{C}_{8} \mathrm{H}_{28} \mathrm{~N}_{2} \mathrm{O}_{13} \mathrm{P}_{4}(484.2) & & & \\
\text { Calcd } & \mathrm{C} 19.84 & \mathrm{H} 5.41 & \text { N } 5.79 & \text { P } 25.6 \%, \\
\text { Found } & \text { C } 19.44 & \text { H } 5.63 & \text { N } 5.93 & \text { P } 26.1 \% .
\end{array}
$$

\section{Cyclic dimeric 1-methylaminopentylidene- \\ 1,1-bis-phosphonic anhydride (7 b)}

The phosphonylation of $\mathrm{N}$-methylvaleramide $(4.61 \mathrm{~g}, 40.0 \mathrm{mmol})$ was carried out as above, $25 \%-\mathrm{MeNH}_{2}(60 \mathrm{ml})$ being used to dissolve the precipitate of $\mathbf{7} \mathbf{b}$. The filtered solution $(300 \mathrm{ml})$ was concentrated to $65 \mathrm{~g}$, the precipitate was filtered off, washed with a minimum amount of water and with $\mathrm{Me}_{2} \mathrm{CO}$ to give $8.97 \mathrm{~g}$ of $7 \mathbf{b ~} \mathrm{MeNH}_{2}$ salt. It was dissolved in water $(250 \mathrm{ml})$ with $25 \%$ $\mathrm{MeNH}_{2}(15 \mathrm{ml})$, the solution was acidified with $35 \%-\mathrm{HCl}(75 \mathrm{ml})$. The treatment analogous to that for $7 \mathbf{a}$ yielded $8.62 \mathrm{~g}(80 \%)$ of $7 \mathbf{b}$ trihydrate.

$$
\begin{aligned}
& \mathrm{C}_{12} \mathrm{H}_{36} \mathrm{~N}_{2} \mathrm{O}_{13} \mathrm{P}_{4} \text { (540.3) } \\
& \text { Calcd C } 26.67 \text { H } 6.72 \% \text {, } \\
& \text { Found C } 26.85 \text { H } 6.87 \% \text {. }
\end{aligned}
$$

\section{Cyclic dimeric 1-methylaminooctylidene- \\ 1,1-bis-phosphonic anhydride (7 c)}

With the exception of the replacement of $\mathrm{MeNH}_{2}$ with $\mathrm{Me}_{2} \mathrm{NH}$, the procedure was analo- gous to that used for the preparation of $\mathbf{7} \mathbf{b}$, yield $9.71 \mathrm{~g}(80 \%)$ of $7 \mathrm{c}$ dihydrate.

$$
\begin{aligned}
& \mathrm{C}_{18} \mathrm{H}_{46} \mathrm{~N}_{2} \mathrm{O}_{12} \mathrm{P}_{4} \text { (606.5) } \\
& \text { Calcd C } 35.65 \text { H 7.64\%, } \\
& \text { Found C } 36.03 \text { H 7.78\%. }
\end{aligned}
$$

\section{Cyclic dimeric 1-methylaminododecylidene-}

\section{1,1-bis-phosphonic anhydride (7 d)}

Crude 7d (14.25 g) was obtained as above from $\mathrm{N}$-methyllauramide $(8.53 \mathrm{~g}, \quad 40.0 \mathrm{mmol})$. The substance contained the only phosphorus-bearing impurity of $\mathbf{6 d}(7 \%)$. It was dissolved in water (8 l) with addition of $33 \%-\mathrm{Me}_{2} \mathrm{NH}(60 \mathrm{ml})$, the filtered solution was concentrated to $270 \mathrm{~g}$. The precipitate was filtered off, washed with water and with $\mathrm{Me}_{2} \mathrm{CO}$ to give $12.26 \mathrm{~g}$ of pure $7 \mathbf{d ~} \mathrm{Me}_{2} \mathrm{NH}$ salt. The product was suspended in water $(375 \mathrm{ml})$ and acidified with $35 \%-\mathrm{HCl}(112 \mathrm{ml})$. The suspension was heated on a steam bath for $0.5 \mathrm{~h}$ with stirring and allowed to stand for a day. The precipitate was filtered off, washed with $10 \%-\mathrm{HCl}$, with water, with $\mathrm{Me}_{2} \mathrm{CO}$, and air-dried to yield $10.50 \mathrm{~g}$ $(73 \%)$ of $\mathbf{7 d}$ dihydrate.

$$
\begin{array}{rrrrr}
\mathrm{C}_{26} \mathrm{H}_{62} \mathrm{~N}_{2} \mathrm{O}_{12} \mathrm{P}_{4}(718.7) & & & \\
\text { Calcd } & \mathrm{C} 43.45 & \mathrm{H} 8.69 & \mathrm{~N} 3.90 & \mathrm{P} 17.2 \%, \\
\text { Found } & \mathrm{C} 43.14 & \mathrm{H} 8.59 & \mathrm{~N} 3.74 & \mathrm{P} 17.5 \% .
\end{array}
$$

Cyclic dimeric p-tolyl (methylamino) methylene-bisphosphonic anhydride (7e)

The procedure was similar to that used for the synthesis of $7 \mathrm{c}$, yield $7.86 \mathrm{~g}(65 \%)$ of $7 \mathrm{e}$ trihydrate.

$$
\begin{aligned}
& \mathrm{C}_{18} \mathrm{H}_{32} \mathrm{~N}_{2} \mathrm{O}_{13} \mathrm{P}_{4} \text { (608.4) } \\
& \text { Calcd C } 35.54 \text { H } 5.47 \% \text {, } \\
& \text { Found C } 35.60 \text { H } 5.51 \% \text {. }
\end{aligned}
$$

\section{Cyclic dimeric 1-butylaminopentylidene-}

\section{1,1-bis-phosphonic anhydride (7f)}

The phosphonylation of N-butylvaleramide $(6.29 \mathrm{~g}, 40.0 \mathrm{mmol})$ was carried out as above, $33 \%-\mathrm{Me}_{2} \mathrm{NH}(60 \mathrm{ml})$ being used to dissolve $7 \mathbf{f}$ precipitate. The solution was evaporated in vacuo, the residue was dissolved in water and filtered through Polyamide Woelm $T L C^{\circledR}$. The filtrate $(140 \mathrm{~g})$ was acidified with $35 \%-\mathrm{HCl}(40 \mathrm{ml})$ at $80-90{ }^{\circ} \mathrm{C}$ and allowed to cool to $20-25^{\circ} \mathrm{C}$. The crystals were filtered off, washed with $8 \%-\mathrm{HCl}$ and with $\mathrm{Me}_{2} \mathrm{CO}$ to yield $8.24 \mathrm{~g}(66 \%)$ of $7 \mathrm{f}$ trihydrate. The product was reprecipitated from water- $\mathrm{Me}_{2} \mathrm{NH}$ with an excess of $\mathrm{HCl}$.

$$
\begin{aligned}
& \mathrm{C}_{18} \mathrm{H}_{48} \mathrm{~N}_{2} \mathrm{O}_{13} \mathrm{P}_{4} \text { (624.5) } \\
& \text { Calcd C } 34.62 \text { H 7.75\%, } \\
& \text { Found C } 34.21 \text { H 7.63\%. }
\end{aligned}
$$


Cyclic dimeric 1-hexylaminopentylidene-

\section{1,1-bis-phosphonic anhydride (7. $\mathbf{g})$}

The synthesis, isolation and purification of the compound were the same as for $7 \mathbf{f}$ to yield $8.26 \mathrm{~g}$ $(59 \%)$ of $7 \mathbf{g}$ tetrahydrate.

$$
\begin{aligned}
& \mathrm{C}_{22} \mathrm{H}_{58} \mathrm{~N}_{2} \mathrm{O}_{14} \mathrm{P}_{4} \text { (698.6) } \\
& \text { Calcd C } 37.82 \mathrm{H} 8.37 \% \text {, } \\
& \text { Found C } 37.75 \text { H } 8.28 \% \text {. }
\end{aligned}
$$

\section{1-Octylaminopentylidene-1,1-bis-phosphonic acid (6h)}

N-Octylvaleramide $(8.54 \mathrm{~g}, 40.0 \mathrm{mmol})$ was phosphonylated as above, $33 \%-\mathrm{Me}_{2} \mathrm{NH}(60 \mathrm{ml})$ being used to dissolve $\mathbf{6 h}$ precipitate. The solution $(250 \mathrm{ml})$ was extracted with $\mathrm{CHCl}_{3}$, the aqueous layer being concentrated to $140 \mathrm{~g}$ and icidified with $35 \%-\mathrm{HCl}(60 \mathrm{ml})$ at $80-90{ }^{\circ} \mathrm{C}$. When rubbing, the resinous precipitate gradually transformed into a crystalline product. The suspension was heated on a steam bath for 5 min and allowed to stand for a day. The crystals were filtered off, washed with $5 \%-\mathrm{HCl}$, water and $\mathrm{Me}_{2} \mathrm{CO}$ to yield after drying $10.19 \mathrm{~g}(71 \%)$ of $\mathbf{6 h}$. The product was recrystallized from azeotropic $\mathrm{HCl}$ and dried in vacuo at $60{ }^{\circ} \mathrm{C}$.

$$
\begin{aligned}
& \mathrm{C}_{13} \mathrm{H}_{31} \mathrm{NO}_{6} \mathrm{P}_{2} \text { (359.3) } \\
& \text { Calcd C } 43.45 \text { H } 8.70 \% \text {, } \\
& \text { Found C } 43.68 \mathrm{H} \mathrm{9.12 \% .}
\end{aligned}
$$

Cyclic dimeric 1-aminooctylidene-1,1-bisphosphonic anhydride (7i)

A phosphonylation mixture was prepared from $\mathrm{PhCl}(8 \mathrm{ml}), 46.4 \%-\mathrm{HBr}(4.84 \mathrm{~g}$ containing $2.59 \mathrm{~g}$, $144.0 \mathrm{mmol}$ of water), $\mathrm{Bu}_{3} \mathrm{~N}(3.11 \mathrm{~g}, 16.8 \mathrm{mmol})$ and $\mathrm{PBr}_{3} \quad(16.35 \mathrm{~g}, \quad 60.4 \mathrm{mmol})$. Caprylamide $(5.01 \mathrm{~g}, 35.0 \mathrm{mmol})$ was added at $25^{\circ} \mathrm{C}$, the mixture was heated to $85-90{ }^{\circ} \mathrm{C}$ and the second portion of $\mathrm{PBr}_{3}(8.01 \mathrm{~g}, 29.6 \mathrm{mmol})$ was added dropwise during $20 \mathrm{~min}$ with intense stirring. The frothy mixture was stirred at $100-102^{\circ} \mathrm{C}$ for $11 \mathrm{~h}$ and allowed to cool to $30^{\circ} \mathrm{C}$. Water $(50 \mathrm{ml})$ was poured on and the mixture was hydrolyzed at $90-98{ }^{\circ} \mathrm{C}$ for $3 \mathrm{~h}$, with $\mathrm{PhCl}$ being removed. The precipitate was filtered off, washed with $10 \%-\mathrm{HCl}$ and $\mathrm{Me}_{2} \mathrm{CO}$ to give $7.77 \mathrm{~g}$ of crude $7 \mathbf{i}$. According to ${ }^{31} \mathrm{P} \mathrm{NMR}$, the product contained $91 \%$ of $7 \mathbf{i}$ ( $70 \%$ on amide) and $9 \%$ of $6 \mathbf{i}(7 \%$ on amide). The product was purified analogously to $7 \mathbf{d}$, to yield $6.25 \mathrm{~g}(62 \%)$ of $7 \mathbf{i}$ dihydrate.

${ }^{31} \mathrm{P}$ NMR: $\delta+12.1\left(\mathrm{~m}\right.$, with ${ }^{1} \mathrm{H}$ decoupled $\left.-\mathrm{s}\right)$.

$$
\begin{aligned}
& \mathrm{C}_{16} \mathrm{H}_{42} \mathrm{~N}_{2} \mathrm{O}_{12} \mathrm{P}_{4} \text { (578.4) } \\
& \text { Calcd C } 33.22 \text { H } 7.32 \% \text {, } \\
& \text { Found C } 33.21 \text { H 7.40\%. }
\end{aligned}
$$

Cyclic dimeric 1-aminododecylidene-1,1-bisphosphonic anhydride $\mathbf{( 7 \mathbf { j } )}$

Lauronitrile $(6.35 \mathrm{~g}, 35.0 \mathrm{mmol})$ was added at $25^{\circ} \mathrm{C}$ to a phosphonylation mixture of $\mathrm{PhCl}$ $(7 \mathrm{ml}), \quad 45.8 \%-\mathrm{HBr} \quad(5.94 \mathrm{~g}$ containing $3.22 \mathrm{~g}$, $178.7 \mathrm{mmol}$ of water), $\mathrm{Bu}_{3} \mathrm{~N}(3.11 \mathrm{~g}, 16.8 \mathrm{mmol})$, and $\mathrm{PBr}_{3}(16.51 \mathrm{~g}, 61.0 \mathrm{mmol})$. The second portion of $\mathrm{PBr}_{3}(7.88 \mathrm{~g}, 29.1 \mathrm{mmol})$ was added at $90-96{ }^{\circ} \mathrm{C}$ during $15 \mathrm{~min}$, and the mixture was stirred at $90-100{ }^{\circ} \mathrm{C}$ for $15 \mathrm{~h}$. The hydrolysis and the subsequent filtration (analogous to those for the synthesis of $7 \mathbf{i}$ ) gave $10.92 \mathrm{~g}$ of crude $\mathbf{7 j}$, which contained $94 \%$ ( $85 \%$ on nitrile) of $7 \mathbf{j}$ and $6 \%(5 \%$ on nitrile) of $6 \mathbf{j}$ according to ${ }^{31} \mathrm{P}$ NMR. The product was purified similarly to $\mathbf{7 d}, \mathrm{Et}_{2} \mathrm{NH}$ being used instead of $\mathrm{Me}_{2} \mathrm{NH}$. The yield of $\mathbf{7} \mathbf{j}$ dihydrate was $7.64 \mathrm{~g}(63 \%)$.

${ }^{31} \mathrm{P}$ NMR: $\delta+12.0\left(\mathrm{~m}\right.$, with ${ }^{1} \mathrm{H}$ decoupled $\left.-\mathrm{s}\right)$.

$$
\begin{array}{rrrrr}
\mathrm{C}_{24} \mathrm{H}_{58} \mathrm{~N}_{2} \mathrm{O}_{12} \mathrm{P}_{4}(690.6) & & & \\
\text { Calcd } & \mathrm{C} 41.74 & \mathrm{H} 8.46 & \mathrm{~N} 4.06 & \mathrm{P} 17.9 \%, \\
\text { Found } & \mathrm{C} 41.48 & \mathrm{H} 8.48 & \mathrm{~N} 4.00 & \mathrm{P} 16.9 \% .
\end{array}
$$

The authors are grateful to Dr. J. D. Collins and Albright \& Wilson Co. for assistance in obtaining elemental analyses and high-quality NMR spectra. We also wish to thank Dr. A. V. Yurkovskaya, Dr. Yu. P. Tsentalovich and Dr. O. M. Usov for qualified consultations concerning NMR spectroscopy.

[6] I. S. Alfer'ev, I. L. Kotlyarevskii, N. V. Mikhalin, and A. V. Krasnukhina, Ger. Offen. 3700772 (1988); C. A. 109, 54960a (1988).

[7] K. H. Worms and M. Schmidt-Dunker, in G. M. Kosolapoff and L. Maier (eds): Organic Phosphorus Compounds Vol. 7, P. 15, John Willey, New York a.o. (1976).

[8] I. S. Alferiev, I. L. Kotlyarevsky, N. V. Mikhalin, and V. M. Novikova, Izv. AN SSSR. Ser. khim. 2802 (1983).

[9] J. R. Van Wazer, Phosphorus and Its Compounds, Vol. 1, P. 664, Interscience Publishers Inc., New York (1958).

[10] A. Boese, Ind. and Eng. Chem., Industrial Edition 32, 16 (1940). 